\title{
EVALUATION OF ORGANIC COMPOUNDS AND TRACE ELEMENTS IN AMAZON CREEK BASIN, OREGON, SEPTEMBER 1990
}

By Frank A. Rinella

U.S. GEOLOGICAL SURVEY

Water-Resources Investigations Report 93-4041

Prepared in cooperation with CITY OF EUGENE AND LANE COUNCIL OF GOVERNMENTS

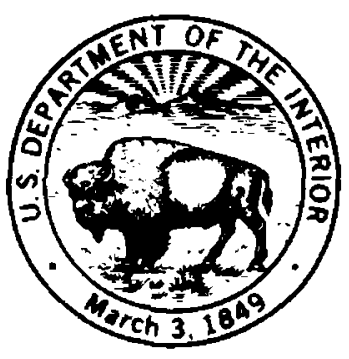

Portland, Oregon 1993 
U.S. DEPARTMENT OF THE INTERIOR

BRUCE BABBITT, Secretary

U.S. GEOLOGICAL SURVEY

ROBERT M. HIRSCH, Acting Director

For additional information write to:

District Chief

U.S. Geological Survey

10615 S.E. Cherry Blossom Drive

Portland, Oregon 97216
Copies of this report can be purchased from:

U.S. Geological Survey

Earth Science Information Center Open-File Reports Section Box 25425, MS 517

Denver Federal Center

Denver, Colorado 80225 


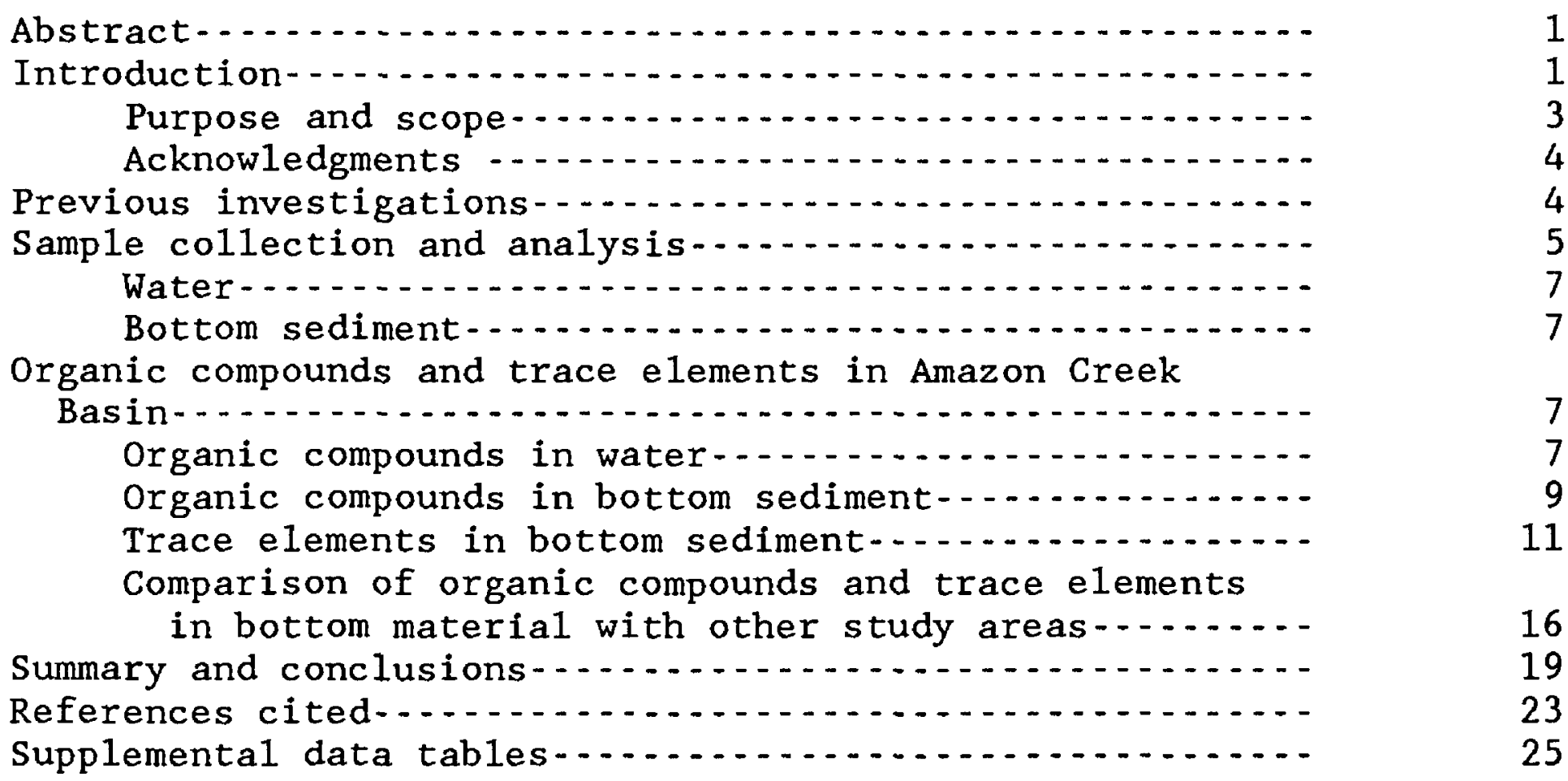


Figure 1. Map showing location of study area and sampling sites in the Amazon Creek Basin,

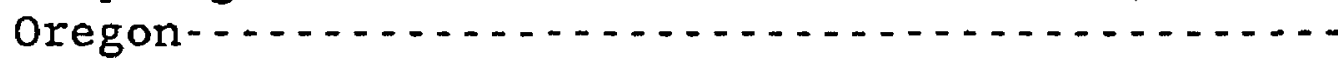

2-6. Graphs showing:

2. Normal-probability plot of silver concentrations in less than 20 micrometersize bottom sediment from the Willamette River-... . . . . . . . . . . . . . . . . . . . . .

3. Boxplots of trace-element concentrations in bottom sediment from Amazon Creek Basin, Johnson Creek, and Portland Harbor for:

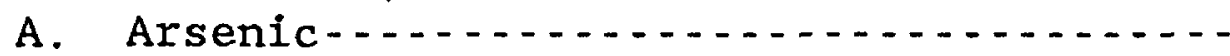

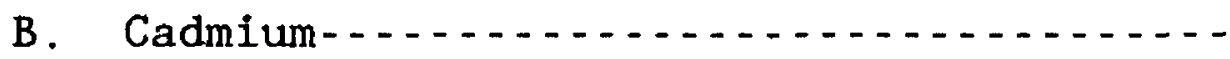

C. Chromium-1......

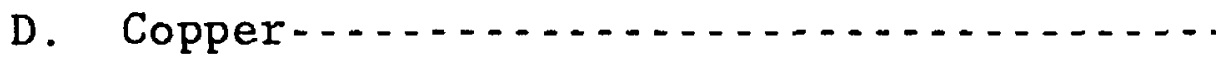

4. Boxplots of trace-element concentrations in bottom sediment from Amazon Creek Basin, Johnson Creek, and Portland Harbor for:
A. Lead-1.........

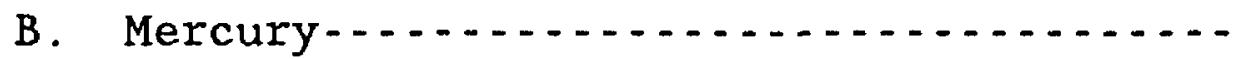

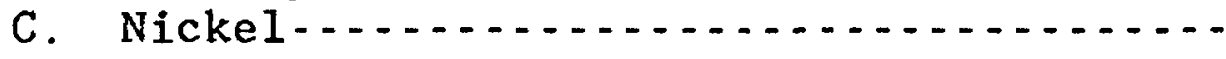

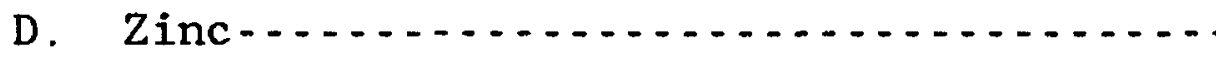

5. Boxplots of organochlorine concentrations in bottom sediment from Amazon Creek Basin and Portland Harbor for:
A. Chlordane -
B. DDT plus metabolites (Johnson Creek data available) ..................

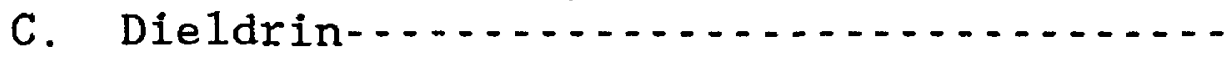

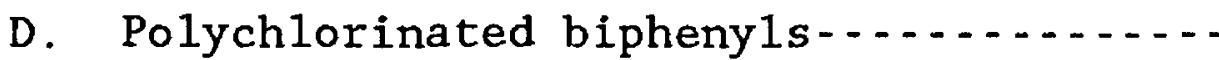

6. Boxplots of semivolatile concentrations in bottom sediment from Amazon Creek Basin and Portland Harbor for:

A. Naphthalene-1................. 21

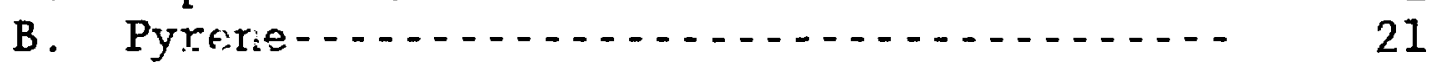

C. Bis(2-ethyl-hexy1)phthalate........ 21 
Table 1. Amazon Creek Basin sampling sites, description of samples collected, and classes of constituents

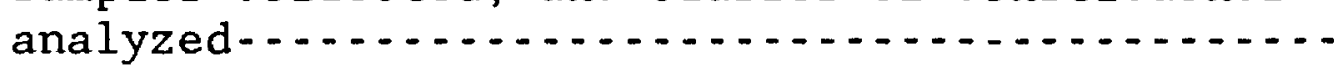

2. Minimum, median, and maximum concentrations of organic compounds detected in whole water from Amazon Creek and A-3 Channe1,

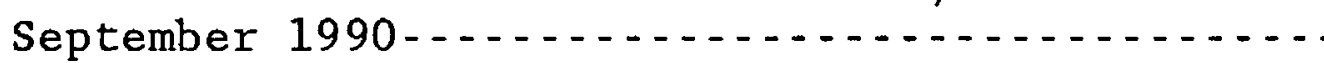

3. Minimum, median, and maximum concentrations of organic compounds detected in bottom sediment from Amazon Creek and A-3 Channel,

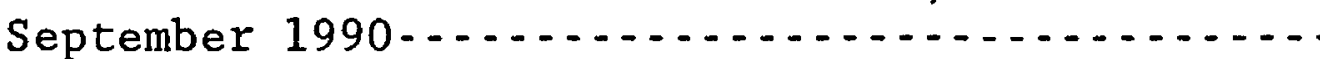

4. Concentrations of total trace elements in Amazon Creek and A-3 Channel bottom sediment that exceeded breakpoint values in Willamette River bottom sediment and baseline values in soils from the Western United States..........

5. Concentrations of total trace elements in Amazon Creek and A-3 Channel bottom sediment that exceeded either proposed Oregon Department of Environmental Quality interim sediment-quality guidelines or proposed Ontario Ministry of the Environment provisional sediment-quality guidelines.-...-.

6. Concentrations of chlorophenoxy-acid herbicides in whole water, Amazon Creek Basin, September 1990-... . . . . . . . . . . . . . . . . . . . . .

7. Concentrations of organophosphorus insecticides in whole water, Amazon Creek Basin, September 1990...........................

8. Concentrations of semivolatile priority pollutants in whole water, Amazon Creek Basin, September 1990..........................

9. Concentrations of carbamate insecticides in whole water, Amazon Creek Basin, September 1990 - . . . . . . . . . . . . . . . . . . . . . .

10. Concentrations of triazine and other nitrogencontaining herbicides in whole water, Amazon Creek Basin, September 1990-...........

11. Concentrations of purgeable organic compounds in whole water, Amazon Creek Basin, September 1990-.........................

12. Concentrations of organochlorine compounds in less than 63 micrometer-size bottom sediment, Amazon Creek Basin, September 1990-...........

13. Concentrations of semivolatile priority pollutants in less than 63 micrometer-size bottom sediment, Amazon Creek Basin,

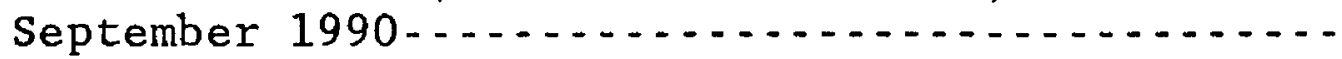

14. Concentrations of total trace elements in bottom sediment, Amazon Creek Basin, September

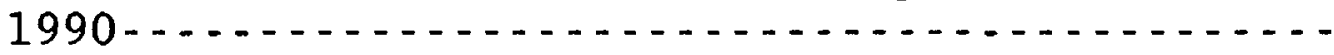


CONVERSION FACTORS AND VERTICAL DATUM

\begin{tabular}{lcl}
\hline Multiply & By & To obtain \\
\hline inch (in.) & 25.4 & millimeter \\
foot (ft) & 0.3048 & meter \\
mile (mi) & 1.609 & kilometer \\
square mile $\left(\mathrm{mi}^{2}\right)$ & 2.590 & square kilometer \\
acre-feet (acre-ft) & 1233. & cubic meter \\
cubic foot per second (ft $\left.{ }^{3} / \mathrm{s}\right)$ & 0.02832 & cubic meter per second \\
ounce, avoirdupois (oz) & 28.35 & gram \\
pound, avoirdupois (1b) & 0.4536 & kilogram \\
gallon (gal) & 3.785 & liter \\
& & \\
\hline
\end{tabular}

Temperature in degrees Celsius $\left({ }^{\circ} \mathrm{C}\right)$ can be converted to degrees Fahrenheit $\left({ }^{\circ} \mathrm{F}\right)$ as follows:

$$
{ }^{\circ} \mathrm{F}=\left({ }^{\circ} \mathrm{C} / 0.555\right)+32
$$

SEA LEVEL: In this report "sea leve1" refers to the National Geodetic Vertical Datum of 1929 (NGVD of 1929) - - a geodetic datum derived from a general adjustment of the first order level nets of both the United States and Canada, formerly called Sea Level Datum of 1929.

The use of trade names in this report is for identification purposes only and does not constitute endorsement by the U.S. Government. 


\title{
EVALUATION OF ORGANIC COMPOUNDS AND TRACE ELEMENTS IN AMAZON CREEK BASIN, OREGON, SEPTEMBER 1990
}

\author{
By Frank A. Rine11a
}

\section{ABSTRACT}

In September 1990, the U.S. Geologica1 Survey, in cooperation with the Lane Council of Governments and the city of Eugene, conducted a reconnaissance study of water quality in Amazon Creek, Oregon. The purpose of the study was to identify the extent of trace-element and organic-compound contamination within the Basin. Water and bottomsediment samples were collected during a summer low-flow condition and analyzed for different classes of organic compounds, including many from the U.S. Environmental Protection Agency's priority pollutant 1ist. Bottom-sediment samples also were analyzed for trace elements typically associated with urban runoff.

Trace-element concentrations in the less-than-63-micrometer fraction of Amazon Creek bottom-sediment samples were compared with baseline concentrations (expected 95-percent confidence interval) for soils from the Western United States and with concentrations found in bottom sediment from the Willamette River Basin. Total-digestion concentrations of antimony, arsenic, cadmium, chromium, cobalt, copper, lead, manganese, mercury, nicke1, silver, titanium, and zinc in bottom sediment from Amazon Creek were enriched at some or all sites sampled.

Whole-water samples from some sites contained measurable concentrations of several chlorophenoxy-acid herbicides (2,4-D, 2,4,5-T, silvex, picloram, and dicamba), an organophosphorus insecticide (diazinon), and several semivolatile priority pollutants

(pentachloropheno1, naphthalene, and pyrene). Classes of compounds not detected in whole-water samples include carbamate insecticides, triazine and other nitrogen-containing herbicides, and purgeable organic compounds. Bottom-sediment samples contained many organic compounds, including chlordane, DDT plus metabolites, dieldrin, endrin, heptachlor epoxide (a metabolite of heptachlor), and PCBs at some or all sites sampled. Twenty-four of 54 semivolatile compounds (including pentachloropheno1, naphthalene, and pyrene) designated as priority pollutants by the U.S. Environmental Protection Agency were detected in bottom-sediment samples at some or all sites sampled.

\section{INTRODUCTION}

Amazon Creek flows in a predominantly west-northwesterly direction as it passes through the City of Eugene, Oregon (fig. 1). Land use along Amazon Creek falls into three distinct zones (City of Eugene, 1987). The upper part of the basin is characterized by single- and multifamily residences. The middle part of the basin is predominantly commercial with some older residential areas interspersed. The lower 


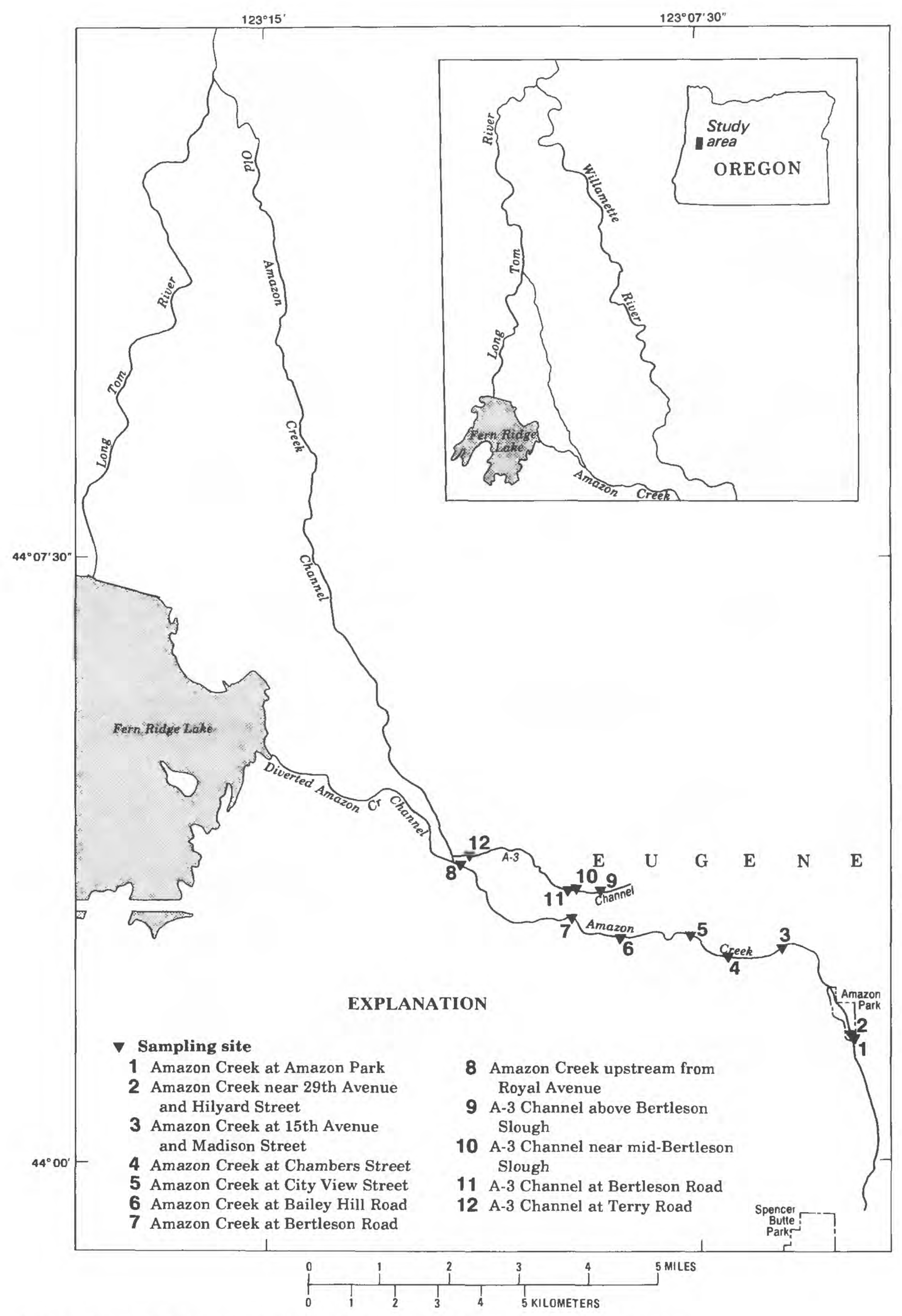

Figure 1. Location of study area and sampling sites in the Amazon Creek Basin, Oregon. 
part is predominantly commercial and light industrial, and is undergoing extensive residential development. The lower part of the basin is currently under considerably more development than the upper part.

The extensive development in the basin has affected a number of beneficial water uses. Recently (1988), the Oregon Department of Environmental Quality (ODEQ) recommended designating the lower 21 miles of Amazon Creek under an Al listing, indicating severe impairment of one or more of its beneficial uses. The affected beneficial uses of Amazon Creek include warm-water fishery, health of aquatic life and wildlife, water-contact recreation, and aesthetic quality (Oregon Department of Environmental Quality, 1988; 1989). Elevated water temperature, and elevated concentrations of bacteria, nutrients, and toxic organic compounds and trace elements have been observed in Amazon Creek, chiefly from industrial point-source discharges and urban runoff (Oregon Department of Environmental Quality, 1988; 1990).

The city of Eugene is growing rapidly in size and population, and its urban growth boundary is encroaching on designated wetland areas. In order to comply with existing Federal and State wetland laws and policies, the Lane Council of Governments (L-COG) and various city of Eugene departments and divisions have prepared a plan to protect remaining valuable wetlands in west Eugene (designated the West Eugene Wetland Special Area Study [WEWSAS]). This plan includes part of the Amazon Creek drainage and provides a mechanism for protecting wetlands by directing development away from sensitive areas and by encouraging development in areas where environmental damage is minimal (Lane Council of Governments, 1991). To this end, it is important that local authorities have an accurate and current assessment of water-quality conditions in Amazon Creek and its associated wetlands. With this knowledge, L-COG and various city agencies will be better equipped to identify sources of contaminants and effects of various land-use activities and to develop management alternatives to either minimize or remove the causes of these effects.

In 1990, the city of Eugene and L-COG, in cooperation with the U.S. Geological Survey (USGS), conducted a reconnaissance study of water quality of Amazon Creek. The purpose of the study was to identify the extent of trace-element and organic-compound contamination within the basin. The request was in response to the need to meet Federal National. Pollutant Discharge Elimination System (NPDES) requirements and to begin to gain an understanding of potential storm-water and dry-weather pollution problems within the basin.

\section{Purpose and Scope}

This report presents an evaluation of water-quality (primarily trace elements and pesticide levels) conditions in the Amazon Creek Basin based on a reconnaissance study.

The objectives of the reconnaissance were:

1. To supplement existing historical data by sampling bottom sediment and water from selected locations within the Amazon Creek drainage basin during a summer low-flow condition. The water and bottomsediment samples were analyzed for different classes of organic compounds, including many from the U.S. Environmental Protection 
Agency's (EPA) priority pollutant list (U.S. Environmental

Protection Agency, 1986). Bottom sediment also was analyzed for a number of trace elements typically associated with urban runoff.

2. To characterize spatial water-quality conditions in Amazon Creek Basin during low flow by using historical data and current trace element and organic compound data.

\section{Acknowledgments}

The author wishes to thank Thomas K. Edwards of the U.S. Geological Survey for coordinating the start-up of this study and for successfully completing the data-collection program. The author wishes to acknowledge also the efforts of Timothy Bringham from the Lane Council of Governments and Deborah Evans from the city of Eugene for their extensive cooperation and for their open exchange of information.

\section{PREVIOUS INVESTIGATIONS}

Water-quality characteristics have been measured in parts of Amazon Creek Basin by various organizations since the mid- to late 1970's. For example, since 1975, ODEQ has collected numerous miscellaneous waterquality samples in the basin. From 1976-77, Jordan Advent and Associates (1977) collected water-quality samples to calibrate a stormwater loading model for six basins in the Eugene/Springfield area (two subbasins of the Amazon Creek Basin) to simulate and predict pollutant loadings to receiving streams. This investigation was conducted for LCOG as part of a Section 208 (PL 92-500) Wastewater Management Study. Rainfall and runoff data and water-quality samples were collected for several storms in 1976 and 1977. One storm was sampled in 1976 in Amazon Creek, and one storm was sampled in 1976 in the Bertleson Road subbasin of the Amazon Creek Basin. Storm-water samples were analyzed for suspended solids, biochemical oxygen demand, orthophosphate, and total-coliform bacteria. No storm-water samples were collected during this study for analysis of trace elements or organic compounds.

From 1980 to 1981, L-COG, the cities of Eugene and Springfield, and CH2M-Hil1 cooperated in a National Urban Runoff Program (NURP) study (Lane Council of Governments, 1981). Samples were collected during this study to assess the cause and severity of runoff contamination and to define potential mitigation measures. In the Amazon Creek Basin, samples were collected monthly at selected sites as well as during approximately three storm events per subbasin. Water samples were analyzed for trace elements, organic compounds, bacteria, nutrients, and major ions. Whole-water concentrations of iron, lead, zinc, mercury, chromium, copper, and nickel at selected sites in Amazon Creek and A-3 Channel exceeded the 4-day EPA criteria established for the protection of aquatic life from chronic toxicity (U.S. Environmental Protection Agency, 1986). The herbicide 2,4-D was detected at a number of sites in Amazon Creek and ranged in concentration from 0.16 to 0.40 $\mu \mathrm{g} / \mathrm{L}$ (micrograms per liter). During two periods of storm runoff in 1981, detectable quantities of trace-organic priority pollutants were found in whole-water samples collected from A-3 Channel.

Pentachlorophenol in storm-runoff samples ranged in concentration from non-detect to $28 \mu \mathrm{g} / \mathrm{L}$. At a $\mathrm{pH}$ of 6.5 , the 4-day EPA criteria for pentachlorophenol for the protection of freshwater aquatic life from 
chronic toxicity is $3.5 \mu \mathrm{g} / \mathrm{L}$. Fluoranthene, naphthalene, $\mathrm{N}$-nitrosodiphenylamine, di-n-octyl phthalate, anthracene, fluorene, phenanthrene, and pyrene were detected in storm runoff in trace amounts from 1 to $4 \mu \mathrm{g} / \mathrm{L}$. A number of chlorinated and brominated volatile organic compounds (including carbon tetrachloride, chlorobenzene, trichloroethylene, and tetrachloroethylene) also were found in storm runoff in trace amounts from 1 to $5 \mu \mathrm{g} / \mathrm{L}$.

An investigation was conducted on Fern Ridge Lake (fig. 1) in 1981-82 under the Clean Lakes Program (section 314 of the Clean Water Act) [Land Council of Governments, 1983]. Fern Ridge Lake was one of seven lakes investigated in Oregon to assure that the Nation's major metropolitan areas had access to swimmable lakes. Even though the objectives of the Clean Lakes Program included identifying waterquality problems and recommending measures to restore or improve water quality in the lake, water quality of the inflowing tributaries, including Amazon Creek, were examined. Most of the constituents analyzed were related to alkalinity, hardness, carbonaceous biochemical-oxygen demand, turbidity, nutrients, and bacteria. Water samples also were collected for analysis of totalrecoverable concentrations of iron, lead, and arsenic in whole water. Iron concentrations ranged from 400 to $2,000 \mu \mathrm{g} / \mathrm{L}$, with a median value of $905 \mu \mathrm{g} / \mathrm{L}$; lead concentrations ranged from 2 to $26 \mu \mathrm{g} / \mathrm{L}$, with a median value of $5.5 \mu \mathrm{g} / \mathrm{L}$; and all arsenic concentrations were $<10 \mu \mathrm{g} / \mathrm{L}$. Iron concentrations for 6 of the 16 samples and lead concentrations for 15 of the 16 samples exceeded the EPA's criteria for the protection of freshwater aquatic life from chronic toxicity (U.S. Environmental Protection Agency, 1986). EPA's freshwateraquatic-1ife, chronic-toxicity criterion for iron is $1,000 \mu \mathrm{g} / \mathrm{L}$, whereas the criteron for lead is hardness dependent and varied in Amazon Creek from 0.5 to $3.6 \mu \mathrm{g} / \mathrm{L}$.

In 1990, ODEQ collected bed-sediment samples adjacent to two wood preserving facilities in the Eugene area. Polychlorinated dibenzo-pdioxin (PCDD) and polychlorinated dibenzo-p-furan (PCDF) compounds were detected in bed sediment at concentrations ranging from tens to hundreds of picograms per gram (Eugene P. Foster, Oregon Department of Environmental Quality, written commun., 1991). A 1992 sampling of bottom sediment in the A-3 Channe1 drainage by the USGS confirmed the presence of trace amounts of PCDDs and PCDFs.

\section{SAMPLE COLLECTION AND ANALYSIS}

Surface-water and bottom-sediment samples were collected from the Amazon Creek and A-3 Channel during September 1990. A-3 Channel is a tributary to Amazon Creek. Because this was a reconnaissance investigation, sampling and analyses were done only at select sites to discern which constituents may be of some concern and would warrant further study. Locations of the sampling sites are shown in figure 1. A description of the types of samples collected and classes of constituents analyzed are given in table 1. Analytica1 results are listed in supplemental data tables 6-14 located at the back of this report. 
Table 1.--Amazon Creek Basin sampling sites, description of samples collected, and classes of constituents analyzed

[WW $=$ whole water; $\mathrm{BS}=$ bottom sediment; $\mathrm{CA}=$ chlorophenoxy-acid herbicides; $O P=$ organophosphorus insecticides; $C I=$ carbamate insecticides;

$\mathrm{TH}=$ triazine and other nitrogen-containing herbicides; $\mathrm{PP}=$ semivolatile priority pollutants; $\mathrm{PO}=$ purgeable organic compounds; $O C=$ organochlorine compounds; $\mathrm{TE}=$ trace elements]

\begin{tabular}{|c|c|c|c|}
\hline $\begin{array}{l}\text { Samp } \\
\text { site }\end{array}$ & Site name & $\begin{array}{l}\text { Sample } \\
\text { type }\end{array}$ & $\begin{array}{l}\text { Classes of } \\
\text { constituents }\end{array}$ \\
\hline 1 & Amazon Creek at Amazon Park & BS & $\begin{array}{l}\text { OC and PP (area } \\
\text { replicate of } \\
\text { sample collected } \\
\text { at } 29 \text { th Avenue and } \\
\text { Hilyard Street) }\end{array}$ \\
\hline 2 & $\begin{array}{l}\text { Amazon Creek near } 29 \text { th Avenue and } \\
\text { Hilyard Street }\end{array}$ & $\begin{array}{l}\text { WW } \\
\text { BS }\end{array}$ & $\begin{array}{l}\mathrm{CA}, \mathrm{OP}, \mathrm{CI}, \mathrm{TH}, \mathrm{PP}, \mathrm{PO} \\
\mathrm{TE}, \mathrm{OC}, \mathrm{PP}\end{array}$ \\
\hline 3 & $\begin{array}{l}\text { Amazon Creek at } 15 \text { th Avenue and Madison } \\
\text { Street }\end{array}$ & BS & $\mathrm{TE}, \mathrm{OC}, \mathrm{PP}$ \\
\hline 4 & Amazon Creek at Chambers Street & BS & $\mathrm{TE}, \mathrm{OC}, \mathrm{PP}$ \\
\hline 5 & Amazon Creek at City View Street & $\begin{array}{l}\text { WW } \\
\text { BS }\end{array}$ & $\begin{array}{l}\mathrm{CA}, \mathrm{OP}, \mathrm{CI}, \mathrm{TH}, \mathrm{PP}, \mathrm{PO} \\
\mathrm{TE}, \mathrm{OC}, \mathrm{PP}\end{array}$ \\
\hline 6 & Amazon Creek at Bailey Hill Road & BS & $\mathrm{TE}, \mathrm{OC}, \mathrm{PP}$ \\
\hline 7 & Amazon Creek at Bertleson Road & $\begin{array}{l}\text { WW } \\
\text { BS }\end{array}$ & $\begin{array}{l}\mathrm{CA}, \mathrm{OP}, \mathrm{CI}, \mathrm{TH}, \mathrm{PP}, \mathrm{PO} \\
\mathrm{TE}, \mathrm{OC}, \mathrm{PP}\end{array}$ \\
\hline 8 & Amazon Creek upstream trom Royal Avenue & $\begin{array}{l}\text { WW } \\
\text { BS }\end{array}$ & $\begin{array}{l}\mathrm{CA}, \mathrm{OP}, \mathrm{CI}, \mathrm{TH}, \mathrm{PP}, \mathrm{PO} \\
\mathrm{TE}, \mathrm{OC}, \mathrm{PP}\end{array}$ \\
\hline 9 & A-3 Channel above Bertleson Slough & $\begin{array}{l}\text { WW } \\
\text { BS }\end{array}$ & $\begin{array}{l}\mathrm{CA}, \mathrm{OP}, \mathrm{CI}, \mathrm{TH}, \mathrm{PP}, \mathrm{PO} \\
\mathrm{TE}, \mathrm{OC}, \mathrm{PP}\end{array}$ \\
\hline 10 & A-3 Channel near mid-Bertleson Slough & $\begin{array}{l}\text { WW } \\
\text { BS }\end{array}$ & $\begin{array}{l}\mathrm{CA}, \mathrm{OP}, \mathrm{CI}, \mathrm{TH}, \mathrm{PP}, \mathrm{PO} \\
\mathrm{TE}, \mathrm{OC}, \mathrm{PP}\end{array}$ \\
\hline 11 & A-3 Channel at Bertleson Road & $\begin{array}{l}\text { WW } \\
\text { BS }\end{array}$ & $\begin{array}{l}\mathrm{CA}, \mathrm{OP}, \mathrm{CI}, \mathrm{TH}, \mathrm{PP}, \mathrm{PO} \\
\mathrm{TE}, \mathrm{OC}, \mathrm{PP}\end{array}$ \\
\hline 12 & A-3 Channel at Terry Road & $\begin{array}{l}\text { WW } \\
\text { BS }\end{array}$ & $\begin{array}{l}\mathrm{CA}, \mathrm{OP}, \mathrm{CI}, \mathrm{TH}, \mathrm{PP}, \mathrm{PO} \\
\mathrm{TE}, \mathrm{OC}, \mathrm{PP}\end{array}$ \\
\hline
\end{tabular}




\section{Water}

Whole-water samples analyzed for organic compounds were collected using 1-liter, hexane-rinsed and baked, narrow-mouth, amber glass bottles fitted with Teflon-lined screw caps. Depth- and widthintegrated water samples were collected by hand-dipping the glass bottle through the water column at intervals along a cross section of the channel. The water samples were preserved by chilling with ice to below $4^{\circ} \mathrm{C}$ (degrees Celsius). These samples were shipped on ice to the U.S. Geological Survey, Water Resources Division, National Water Quality Laboratory, located in Arvada, Colorado, and analyzed according to procedures described by Wershaw and others (1987).

\section{Bottom Sediment}

Bottom-sediment samples were collected using a $250-\mathrm{mL}$ (milliliter) baked, glass beaker. Only the top 1-2 centimeters of bottom sediment were collected. Twenty to 25 points in the cross section at each site were randomly sampled and composited (volume weight) into a $500-\mathrm{mL}$ hexane-rinsed, baked, wide-mouth, glass bottle fitted with a teflonlined screw cap.

Bottom-sediment samples for trace-element analysis were wet-sieved

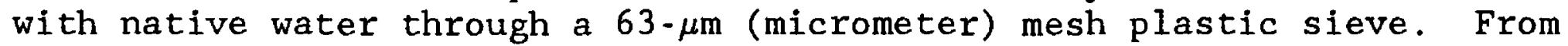
each site, approximately $150-200 \mathrm{mg}$ (milligrams) of the $<63-\mu \mathrm{m}$ sizefraction and 150-200 $\mathrm{mg}$ of the $>63-\mu \mathrm{m}$ size-fraction materials were placed in individual $125-\mathrm{mL}$ plastic containers and frozen with dry ice. These samples were shipped on dry ice to Dr. Arthur J. Horowitz at the U.S. Geological Survey, Water Resources Division research laboratory, Atlanta, Georgia, and analyzed for total trace-element concentrations (Horowitz, 1991). The analysis involved digestion of the sediment in hot hydrofluoric acid which removes trace-element adsorbates and extracts most trace elements from surface coatings and the sediment matrix.

Bottom-sediment samples for analysis of organic compounds were wetsieved with native water through a $63-\mu \mathrm{m}$ mesh stainless-steel sieve. Approximately 300-400 g (grams) of $<63-\mu \mathrm{m}-$ size bottom sediment from each site were placed into an individual $500 \mathrm{~mL}$ hexane-rinsed, baked, widemouth, glass bottle fitted with a teflon-lined screw cap. The organic samples were preserved by chilling with ice to below $4^{\circ} \mathrm{C}$. These samples were shipped on ice to the U.S. Geological Survey, Water Resources Division, National Water Quality Laboratory, Arvada, Colorado, and analyzed according to procedures described by Wershaw and others (1987).

\section{ORGANIC COMPOUNDS AND TRACE ELEMENTS IN AMAZON CREEK BASIN}

\section{Organic Compounds in Water}

During the September 1990 reconnaissance, whole-water samples were collected at eight sites in Amazon Creek and A-3 Channel. Four of the eight sites were located in Amazon Creek upstream of A-3 Channel (fig. 1 , table 1). The other four sites were located in A-3 Channel. 
Whole-water concentrations of chlorophenoxy-acid herbicides, organophosphorus insecticides, and semivolatile priority pollutants were detected at a number of the sites in Amazon Creek and A-3 Channel. Classes of compounds not detected included carbamate insecticides, triazine and other nitrogen-containing herbicides, and purgeable organic compounds. The compounds detected and their concentration ranges are summarized in table 2 and are tabulated individually in supplemental data tables 6 through 11 .

Detectable concentrations of the chlorophenoxy-acid herbicides 2,4-D, 2,4,5-T, picloram, and dicamba were found in Amazon Creek. Detectable levels of 2,4-D, silvex $(2,4,5-\mathrm{TP})$, and picloram were found in A-3 Channe1 (table 2 and supplemental data table 6). Most of the chlorophenoxy-acid herbicides detected were at levels just above the analytical reporting limits, with the exception of 2,4-D concentrations $(0.07$ to $0.75 \mu \mathrm{g} / \mathrm{L})$ in Amazon Creek. Concentrations of 2,4-D were below the $100-\mu \mathrm{g} / \mathrm{L}$-human-health criterion that the EPA has established for the combination of water and fish ingestion (U.S. Environmental Protection Agency, 1986).

Diazinon was the only organophosphorus insecticide found in Amazon Creek and A-3 Channe1 (table 2 and supplemental data table 7). Although diazinon was detected at the analytical reporting limit $(0.01 \mu \mathrm{g} / \mathrm{L})$, these concentrations exceed the National Academy of Sciences 1972 maximum concentration of $0.009 \mu \mathrm{g} / \mathrm{L}$ recommended for the protection of freshwater aquatic life from chronic toxicity (National Academy of Sciences, 1973). No criterion is listed for diazinon in EPA's 1986 quality criteria for water report (U.S. Environmental Protection Agency, 1986).

Table 2.-Minimum, median, and maximum concentrations of organic compounds detected (greater than analytical reporting limit) in whole water from Amazon Creek and A-3 Channel, September 1990

[Detected concentrations are listed as Min/Med/Max (minimum/median/maximum) values in micrograms per liter; "-" indicates all determinations were less than analytical reporting limit; where only two concentrations detected, the average is reported as the median value; $2,4-D=2,4$-dichlorophenoxy acetic acid; $2,4,5-T=2,4,5$-trichlorophenoxy acetic acid]

\begin{tabular}{|c|c|c|c|c|c|c|c|c|}
\hline \multirow[b]{2}{*}{ Compound } & \multicolumn{4}{|c|}{ Amazon Creek } & & \multicolumn{3}{|c|}{ A-3 Channel } \\
\hline & $\begin{array}{l}\text { Number of } \\
\text { samples }\end{array}$ & $\begin{array}{l}\text { Number of } \\
\text { detections }\end{array}$ & Min/l & Med/Ma: & & $\begin{array}{l}\text { Number of } \\
\text { s amples }\end{array}$ & $\begin{array}{l}\text { Number of } \\
\text { detections }\end{array}$ & $\operatorname{Min} / \operatorname{Med} / \operatorname{Max}$ \\
\hline \multicolumn{9}{|c|}{ Chlorophenoxy acid herbicides } \\
\hline $2,4-D$ & 4 & 4 & \multicolumn{3}{|c|}{$0.07 / 0.20 / 0.75$} & 4 & 2 & $0.01 / 0.02 / 0.02$ \\
\hline $2,4,5-T$ & 4 & 1 & \multicolumn{3}{|c|}{.01} & 4 & 0 & -- \\
\hline Silvex & 4 & 0 & \multicolumn{3}{|c|}{--} & 4 & 1 & .01 \\
\hline Picloram & 4 & 1 & \multicolumn{3}{|c|}{.01} & 4 & 3 & \multirow{2}{*}{$\begin{array}{c}.011 \\
\ldots \\
\ldots\end{array}$} \\
\hline Dicamba & 4 & 3 & $.01 /$ & $.03 /$ & .15 & 4 & 0 & \\
\hline \multicolumn{9}{|c|}{ Organophosphorus insecticides } \\
\hline Diazinon & 4 & 4 & $.01 /$ & $.01 /$ & .01 & 4 & 1 & .01 \\
\hline \multicolumn{9}{|c|}{ Semivolatile priority pollutants } \\
\hline $\begin{array}{l}\text { Pentachloro- } \\
\text { phenol }\end{array}$ & 4 & 0 & & -- & & 4 & 3 & $1.8 / 2.3 / 5.4$ \\
\hline Naphthalene & 4 & 0 & & -- & & 4 & 1 & .08 \\
\hline Pyrene & 4 & 0 & & -- & & 4 & 1 & .08 \\
\hline
\end{tabular}


of the 54 semivolatile priority pollutants analyzed, only pentachlorophenol, naphthalene, and pyrene were detected in whole water (table 2 and supplemental data table 8). These compounds were found only in A-3 Channel. Pentachlorophenol was observed at 3 of the 4 sites sampled and ranged in concentration from 1.8 to $5.4 \mu \mathrm{g} / \mathrm{L}$. Laboratory tests indicate that chronic toxicity from pentachlorophenol has occurred to fresh-water aquatic 1 ife at concentrations as $10 \mathrm{w}$ as $3.5 \mu \mathrm{g} / \mathrm{L}$ at a $\mathrm{pH}$ of 6.5 (U.S. Environmental Protection Agency, 1986). Naphthalene and pyrene were detected at only one site (A-3 Channel at Terry Road at a concentration of $0.08 \mu \mathrm{g} / \mathrm{L}$. Naphthalene was detected at this site below the $620 \mu \mathrm{g} / \mathrm{L}$ EPA criterion for protection of freshwater aquatic life from chronic toxicity (U.S. Environmental Protection Agency, 1986). However, pyrene at this site was detected at a concentration above the polynuclear-aromatic-hydrocarbon (PAH) 1-in-100,000-1ifetime-cancer risk exposure from ingestion of contaminated water and contaminated aquatic organisms (U.S. Environmenta1 Protection Agency, 1986).

\section{Organic Compounds in Bottom Sediment}

During the September 1990 reconnaissance investigation, bottomsediment samples were collected at eight sites in Amazon Creek (one sample at Amazon Park represents an area close to a sample collected at Amazon Creek near 29 th Avenue and Hilyard Street), and at four sites in A-3 Channel (fig. 1, table 1). Bottom-sediment concentrations for eight of 17 organochlorine compounds and for 24 of 54 semivolatile priority pollutants were detected in Amazon Creek and A-3 Channel in the <63- $\mu \mathrm{m}-$ size fraction (table 3 and supplemental data tables 12 and 13).

Chlordane, dichlorodiphenyldichloroethane (DDD), dichlorodiphenyldichloroethylene (DDE), and dichlorodiphenyltrichloroethane (DDT), dieldrin, endrin, heptachlor epoxide, and polychlorinated biphenyls (PCBs) were detected in samples from Amazon Creek; whereas chlordane, DDD, DDE, dieldrin, and PCBs were detected in samples from A-3 Channel (table 3, supplemental data tables 12 and 13). Chlordane, DDD, dieldrin, and PCBs were detected at almost a11 sites sampled in Amazon Creek and A-3 Channel. In addition, seven of the eight organochlorine compounds were found at two Amazon Creek sites (15th Avenue and Madison Street and Chambers Street). Five of the eight compounds (chlordane, DDE, DDT, heptachlor epoxide, and PCBs) detected at the two Amazon Creek sites had either the largest or second largest concentrations when compared to concentrations reported for all sites.

Concentrations of chlordane, DDT and its metabolites (DDE and DDD), dieldrin, endrin, and PCBs in the $<63-\mu \mathrm{m}-\mathrm{size}$ bottom sediment, when normalized for organic carbon content, did not exceed the EPA 97.5percent confidence-interim sediment values (interstitial-water concentrations) proposed for the protection of freshwater benthic fauna from chronic toxicity (U.S. Environmental Protection Agency, 1988 and 1990). However, the PCB concentration at Amazon Creek at 15 th and Madison Street (630 micrograms per kilogram [ $\mu \mathrm{g} / \mathrm{kg}]$ exceeded the proposed ODEQ interim sediment-quality guideline of $500 \mu \mathrm{g} / \mathrm{kg}$ (Eugene $P$. Foster, Oregon Department of Environmental Quality, written commun., 1988). Two other sites in A-3 Channel, above Bertleson Slough and at 
Table 3.--Minimum, median, and maximum concentrations of organic compounds detected in bottom sediment from Amazon Creek and $A-3$ Channel, september 1990

[Detected concentrations are 1 isted as Min/Med/Max (minimum/median/maximum); compound concentrations in bed sediment in micrograms per kilograms; DDD $=$ dichlorodiphenyldichloroethane: $D D E=$ dichlorodiphenyldichloroethylene: DDT $=$ dichlorodiphenyl-

trichloroethane; "-." indicates all determinations were less than analytical reporting

limit; where oniy two concentrations detected, the average is reportd as the median value]

\begin{tabular}{|c|c|c|c|c|c|c|}
\hline Compound & $\begin{array}{l}\text { Number of } \\
\text { samples }\end{array}$ & $\begin{array}{l}\text { Amazon } \\
\text { Number of } \\
\text { samples above } \\
\text { reporting } \\
\text { limits }\end{array}$ & Min/Med/Max & $\begin{array}{l}\text { Number of } \\
\text { samples }\end{array}$ & $\begin{array}{l}\text { N-3 Chan } \\
\text { Number of } \\
\text { s amples above } \\
\text { reporting } \\
\text { limits }\end{array}$ & $\operatorname{Min} / \operatorname{Med} / \operatorname{Max}$ \\
\hline \multicolumn{7}{|c|}{ Organochlorine compounds } \\
\hline Chlordane & 8 & 8 & $38 / 75 / 140$ & 4 & 4 & $9.0 / 32 / 60$ \\
\hline DDD & 8 & 8 & $3.5 / 7.9 / 15$ & 4 & 4 & $4.6 / 50 / 120$ \\
\hline DDE & 8 & 6 & $2.0 / 4.6 / 9.0$ & 4 & 1 & $111 /$ \\
\hline $\mathrm{DDT}$ & 8 & 2 & $2.0 / 2.5 / 3.0$ & 4 & 0 & -- \\
\hline Dieldrin & 8 & 8 & $2.2 / 7.0 / 10$ & 4 & 3 & $0.8 / 1.2 / 1.6$ \\
\hline Endrin & 8 & 1 & 10.11 & 4 & 0 & -- \\
\hline $\begin{array}{l}\text { Heptachlor } \\
\text { epoxide }\end{array}$ & 8 & 5 & $0.8 / 1.6 / 1.8$ & 4 & 0 & -- \\
\hline $\begin{array}{l}\text { Polychlorinated } \\
\text { biphenyls }\end{array}$ & 8 & 8 & $20 / 43 / 630$ & 4 & 4 & $54 / 244 / 450$ \\
\hline \multicolumn{7}{|c|}{ Semivolatile priority pollutants } \\
\hline $\begin{array}{l}\text { Pentachloro- } \\
\text { phenol }\end{array}$ & 8 & 0 & -- & 4 & 4 & $270 / 600 / 770$ \\
\hline Phenol & 8 & 2 & $210 / 370 / 530$ & 4 & 2 & $30 / 45 / 60$ \\
\hline Ac enaphthene & 8 & 0 & -- & 4 & 1 & 1201 \\
\hline Acenaphthylene & 8 & 1 & 151 & 4 & 4 & $10 / 20 / 50$ \\
\hline Anthracene & 8 & 3 & $5 / 5 / 10$ & 4 & 4 & $10 / 20 / 40$ \\
\hline $\begin{array}{l}\text { Benzo a } \\
\text { anthracene }\end{array}$ & 8 & 5 & $10 / 20 / 270$ & 4 & 4 & $30 / 60 / 90$ \\
\hline $\begin{array}{l}\text { Benzo b } \\
\text { fluoranthene }\end{array}$ & 8 & 4 & $40 / 50 / 70$ & 4 & 4 & $50 / 70 / 80$ \\
\hline $\begin{array}{l}\text { Benzo } \mathrm{k} \\
\text { fluoranthene }\end{array}$ & $e^{8}$ & 4 & $40 / 55 / 70$ & 4 & 4 & $50 / 90 / 150$ \\
\hline Benzo a pyrene & 8 & 4 & $30 / 40 / 60$ & 4 & 4 & $40 / 110 / 110$ \\
\hline $\begin{array}{c}\text { Benzo }(g, h, i) \\
\text { perylene }\end{array}$ & 8 & 1 & $/ 10 /$ & 4 & 1 & $150 /$ \\
\hline $\begin{array}{l}\text { N-Butyl benzyl } \\
\text { phthalate }\end{array}$ & 8 & 1 & $/ 240 /$ & 4 & 2 & $220 / 285 / 350$ \\
\hline Chrysene & 8 & 5 & $20 / 70 / 1,200$ & 4 & 4 & $80 / 160 / 210$ \\
\hline $\begin{array}{l}1,2,5,6 \text { Dibenzo- } \\
\text { anthracene }\end{array}$ & 8 & 0 & -- & 4 & 1 & 1301 \\
\hline $\begin{array}{l}\text { 2, } 4 \text { Dichloro- } \\
\text { benzene }\end{array}$ & 8 & 0 & -- & 4 & 3 & $5 / 10 / 10$ \\
\hline $\begin{array}{l}\text { Diethyl } \\
\text { phthalate }\end{array}$ & 8 & 1 & $/ 390 /$ & 4 & 0 & -- \\
\hline $\begin{array}{l}\text { Di-N-octyl } \\
\text { phthalate }\end{array}$ & 8 & 1 & $/ 120 /$ & 4 & 2 & $340 / 420 / 500$ \\
\hline $\begin{array}{l}\text { Bis(2-ethyl-hexy } \\
\text { phthalate }\end{array}$ & $\left(\begin{array}{l}81) \\
8\end{array}\right.$ & 8 & $1,300 / 8,900 / 41,000$ & 4 & 4 & $1,300 / 1,800 / 6,400$ \\
\hline Fluorene & 8 & 0 & -- & 4 & 4 & $10 / 20 / 30$ \\
\hline Fluoranthene & 8 & 8 & $40 / 180 / 1,200$ & 4 & 3 & $120 / 220 / 460$ \\
\hline $\begin{array}{l}\text { Indeno } \\
\text { pyrene }\end{array}$ & d) 8 & 1 & $/ 10 /$ & 4 & 2 & $20 / 50 / 80$ \\
\hline Naphthalene & 8 & 8 & $10 / 50 / 140$ & 4 & 4 & $60 / 70 / 150$ \\
\hline Phenanthrene & 8 & 8 & $20 / 125 / 510$ & 4 & 4 & $70 / 140 / 190$ \\
\hline Pyrene & 8 & 8 & $40 / 175 / 940$ & 4 & 4 & $110 / 190 / 690$ \\
\hline $\begin{array}{l}\text { 1,2,4 Trichloro- } \\
\text { benzene }\end{array}$ & 8 & 0 & -- & 4 & 1 & 151 \\
\hline
\end{tabular}


Bertleson Road, had elevated PCB concentrations of $450 \mu \mathrm{g} / \mathrm{kg}$ and $430 \mu \mathrm{g} / \mathrm{kg}$, respectively. One site on A-3 Channel (mid-Bertleson Slough) had a bottom-sediment DDT-plus-metabolite concentration $(131 \mu \mathrm{g} / \mathrm{kg})$ that approached the proposed ODEQ interim sediment-quality guideline of $200 \mu \mathrm{g} / \mathrm{kg}$ (Eugene P. Foster, Oregon Department of Environmental Quality, written commun., 1988). Because no EPA interim-sediment guideline has been proposed for heptachlor epoxide, its chronic toxicity to freshwater benthic fauna could not be evaluated.

Twenty-three of the 24 semivolatile priority pollutants detected in the basin were found at sites sampled in A-3 Channel; 13 of the compounds (including pentachlorophenol, naphthalene, and pyrene) were detected at all sites sampled in A-3 Channel (table 3 and supplemental data table 13). Pentachlorophenol concentrations are suspected to result from wood-preserving facilities located in the A-3 channe 1 drainage. Although 18 of the 24 compounds also were detected at one or more sites in Amazon Creek, only 5 of the compounds (bis[2-ethylhexyl]phthalate, fluoranthene, naphthalene, phenanthrene, and pyrene) were detected at all sites in Amazon Creek. Of the compounds detected, pentachloropheno1, acenaphthene, 1,2,5,6 dibenzoanthracene, 1,4 dichlorobenzene, fluorene, and 1,2,4 trichlorobenzene were the only compounds not found in Amazon Creek, whereas, diethylphthalate was the only compound not found in A-3 Channel. Concentrations for 18 of the 24 compounds detected in the basin were largest in A-3 Channe1; concentrations for 15 of these 18 were largest at A-3 Channel above Bertleson Slough and (or) at A-3 Channel at Terry Road.

Concentrations of phenanthrene, fluoranthene, pyrene, benzo(a) pyrene, and benzo(a)anthracene in the $<63-\mu \mathrm{m}-\mathrm{size}$ bottom sediment, when normalized for organic carbon content, did not exceed the EPA (1988) 97.5-percent confidence-interim sediment values (interstitial water concentrations) proposed for the protection of freshwater benthic fauna from chronic toxicity. Because no EPA interim-sediment guidelines have been proposed for the remaining 19 semivolatile priority pollutants, their chronic toxicity to freshwater benthic fauna could not be evaluated.

\section{Trace Elements in Bottom Sediment}

During the September 1990 reconnaissance, bottom-sediment samples also were collected from seven sites in Amazon Creek and from four sites in A-3 channel for analysis of total-element concentrations for 16 trace elements ( $\mathrm{fig} .1$; table 1 ). In addition to chemical analyses made on the $<63-\mu \mathrm{m}$ and the $>63-\mu \mathrm{m}$ size fractions (but $<2-\mathrm{mm}$ fraction), percent of sediment in each size fraction, total organic carbon, and surfacearea measurements were analyzed by Arthur J. Horowitz, U.S. Geologica1 Survey, Atlanta, Georgia (supplemental data table 14). Detailed interpretation of the elemental data was limited to the $<63-\mu \mathrm{m}-s i z e$ fraction because bottom-sediment materials $<88 \mu \mathrm{m}$ in size have been shown to be more readily ingested by some bottom-feeding benthic organisms (Luoma, 1983). Bottom-sediment concentrations of most elements in the $<63-\mu \mathrm{m}-\mathrm{size}$ fraction tended to be larger than those concentrations observed in the $>63-\mu \mathrm{m}$ to $<2-\mathrm{mm}-\mathrm{size}$ fraction. 
Two techniques were used to distinguish whether total trace-element concentrations from the 11 sites sampled in Amazon Creek and A-3 Channe1 represented natural background or enrichment. With the first technique, element concentrations in the $<63-\mu \mathrm{m}$-size bottom sediment were compared to bottom-sediment trace-element concentrations from the Willamette River, whose normal-probability distributions for the $<20-\mu \mathrm{m}-\mathrm{size}$ fraction had been defined previously (Rickert and others, 1977). If the $<20-\mu \mathrm{m}$ fraction of Willamette River bottom sediment are derived primarily from weathering of two chemically related rock types (andesite and basalt), the natural background concentrations of a given element composing the rock types would be expected to form one statistical population (as represented by a straight line) on a normal-probability plot. If part of the element's population also was enriched, a second statistical population (represented by a second straight line) comprising the enriched element concentrations would be expected to emerge on the same normal-probability plot. A sharp break in the two curves should occur between the natural background element concentrations (the lower segment of the curve) and the enriched element concentrations (the upper segment of the curve). The breakpoint concentrations in the Willamette River normal-probability plot were used to characterize element enrichment in Amazon Creek and A-3 Channe1. To illustrate this technique, the normal-probability plot for silver concentrations ( $<20-\mu \mathrm{m}-\mathrm{size}$ fraction) for Willamette River bottom sediment (fig. 2) defines a two-stage curve with a breakpoint at a concentration slightly greater than about $1 \mathrm{ppm}$ (parts per million). In this manner, breakpoint values were calculated to evaluate trace-element enrichment in Amazon Creek and A-3 Channel (table 4).

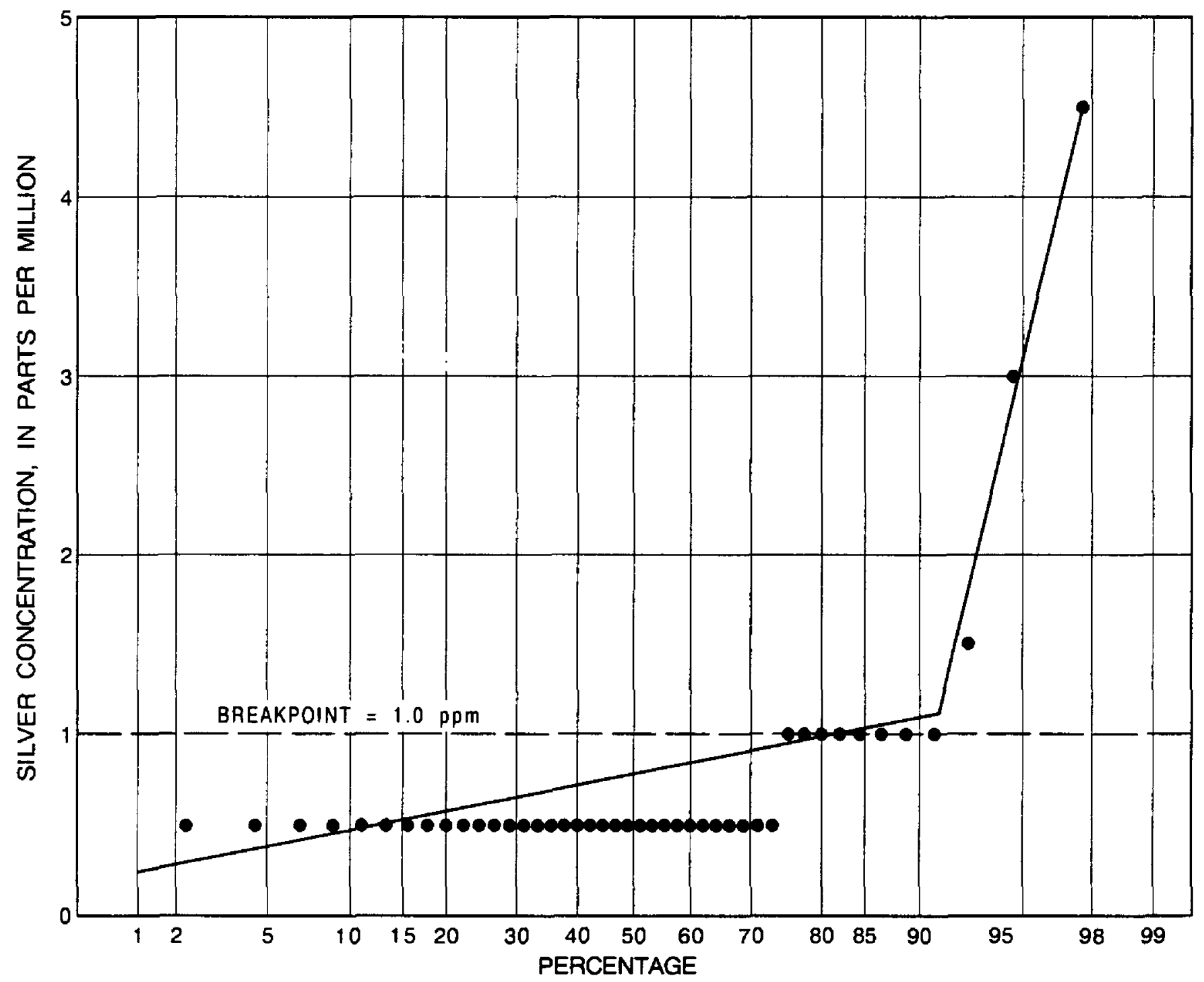

Figure 2. Normal-probability plot of silver concentrations in less than 20 micrometer-size bottom sediment from the Willamette River (Rickert and others, 1977). 
Table 4.-- - Concentrations of total trace elements in Amazon Creek and A-3 Channe1 bottom sediment that exceeded breakpoint values in Willamette River bottom sediment and baseline values in soils from the Western United States

$[\mathrm{Ag}=$ silver $\mathrm{Cu}=$ copper $\mathrm{Pb}=$ lead; $\mathrm{Zn}=$ zinc; $\mathrm{Ni}=$ nickel; $\mathrm{Co}=$ cobalt; $\mathrm{Cd}=$ cadmium; $\mathrm{Cr}=$ chromium; $\mathrm{Hg}=$ mercury; $\mathrm{As}=$ arsenic; $\mathrm{Sb}=$ antimony; $\mathrm{Mn}=$ manganese; and $\mathrm{Ti}=$ titanium. Trace-element concentrations are in parts per million except for $\mathrm{Mn}$ and $\mathrm{Ti}$ which are in percent. Willamette River bottom-sediment breakpoint values, except for $\mathrm{Sb}$, are for particles less than 20 micrometers; geochemical soil baseline bottom-sediment values are for particle-size fraction less than 2 millimeters; $\mathrm{Sb}$ and Amazon Creek bottom-sediment values are for particle-size fraction less than 63 micrometers. na $=$ not available and $*=$ less than breakpoint and baseline values]

\begin{tabular}{|c|c|c|c|c|c|c|c|c|c|c|c|c|c|}
\hline \multirow[b]{2}{*}{ Sampling site } & \multicolumn{13}{|c|}{ Trace Element } \\
\hline & $\mathrm{Ag}$ & $\mathrm{Cu}$ & $\mathrm{Pb}$ & $\mathrm{Zn}$ & $\mathrm{Ni}$ & Co & $\mathrm{Cd}$ & $\mathrm{Cr}$ & $\mathrm{Hg}$ & As & $\mathrm{Sb}$ & Mn & $\mathbf{T} \mathbf{i}$ \\
\hline $\begin{array}{l}\text { Willamette River } \\
\text { Basin breakpoint } \\
\text { values } 1 /\end{array}$ & 1.0 & 45 & 45 & 145 & 40 & 30 & 1.0 & 60 & 0.15 & $<20$ & 1.2 & 0.18 & $<0.7$ \\
\hline $\begin{array}{c}\text { Geochemical soil } \\
\text { baseline } \\
\text { values } 2 /\end{array}$ & na & 90 & 55 & 180 & 66 & 28 & na & 200 & .25 & 22 & na & .15 & .70 \\
\hline $\begin{array}{l}\text { Amazon Creek } \\
\text { Near } 29 \text { th Avenue and }\end{array}$ & & & & & & & & & & & & & \\
\hline $\begin{array}{l}\text { Hilyard Street } \\
\text { At } 15 \text { th Avenue and }\end{array}$ & * & 109 & 217 & 600 & * & 57 & 1.4 & * & * & * & 2.0 & .35 & .75 \\
\hline Madison Street & * & 112 & 277 & 760 & * & 42 & 1.8 & * & .46 & * & 1.7 & * & .71 \\
\hline At Chambers Street & * & 112 & 202 & 600 & * & 34 & 1.3 & * & * & $*$ & 1.5 & * & .85 \\
\hline At City View Street & * & 121 & 162 & 660 & $*$ & 46 & 1.5 & 214 & .26 & 30 & 1.3 & $*$ & .92 \\
\hline At Bailey Hill Road & * & * & 80 & 285 & * & 34 & * & * & * & 37 & * & .23 & .98 \\
\hline $\begin{array}{l}\text { At Bertleson Road } \\
\text { Upstream from Royal }\end{array}$ & 1.1 & 101 & 130 & 535 & 74 & 77 & $*$ & 213 & $*$ & 90 & 1.3 & .27 & .94 \\
\hline Avenue & * & * & 102 & 370 & * & 65 & $*$ & * & $*$ & 34 & * & * & .76 \\
\hline
\end{tabular}

A - 3 Channe1

Above Bertleson Slough Near mid-Bertleson Slough At Bertleson Road At Terry Road

$$
\begin{array}{cccccccccccccc}
4.3 & 141 & 269 & 1,150 & 68 & * & 4.1 & * & 3.84 & * & 2.8 & * & * \\
4.6 & 138 & 286 & 1,050 & 78 & * & 3.0 & * & 4.36 & 26 & 2.4 & * & * \\
2.3 & 91 & 177 & 810 & * & * & 1.9 & * & 2.17 & 33 & 2.2 & * & * \\
* & * & * & 230 & * & * & * & * & .31 & 25 & * & * & .96
\end{array}
$$

1/ Breakpoint concentrations, except for antimony, are data from Rickert and others (1977). Breakpoint concentration for antimony is from T.K. Edwards and D.A. Curtiss (U.S. Geological Survey, written commun., 1990).

2/ R.C. Severson (U.S. Geological Survey, written commun., 1987) based on data in Shacklette and Boerngen (1984). 
The second technique used to evaluate trace-element enrichment in the Amazon Creek Basin involves comparing element concentrations in the $<63-\mu \mathrm{m}-\mathrm{size}$ bottom sediment to the range of geochemical baseline concentrations found in soils west of the 97 th meridian within the conterminous United States (R.C. Severson, U.S. Geological Survey, written commun., 1987, based on data in Shacklette and Boerngen, 1984). The geochemical baseline values (table 4) represent the upper 95-percent statistical-confidence limit for each element's frequency distribution. Amazon Creek Basin bottom-sediment concentrations that exceed the upper 95-percent baseline confidence limit are considered uncommonly high and suggest enrichment.

Thirteen of the 16 elements (silver, copper, lead, zinc, nicke1, cobalt, cadmium, chromium, mercury, arsenic, antimony, manganese, and titanium) analyzed in bottom sediment from Amazon Creek and A-3 Channel exceeded the greater of the Willamette River breakpoint values or the upper 95-percent baseline confidence values for soils from the Western United States (table 4 and table 14). Only selenium, iron, and aluminum concentrations did not indicate enrichment in the Amazon Creek Basin.

Copper, lead, zinc, and antimony concentrations were enriched in almost all bottom-sediment samples collected, while cadmium and arsenic concentrations were enriched in more than one-half of the samples collected. Cobalt, chromium, manganese, and titanium showed predominant enrichment at the Amazon Creek sites; whereas, silver and mercury were enriched predominantly at A-3 Channel sites. Nickel was enriched slightly at only a few sites in both Amazon Creek and A-3 Channel. Median values for the enriched concentrations of cadmium, silver, and mercury in A-3 Channel were from 2 to 8 times larger than median enriched values in Amazon Creek (table 4).

A comparison was made between the mathematically composited traceelement concentrations for the $<63-\mu \mathrm{m}$ plus the $>63-\mu \mathrm{m}-\mathrm{size}$ bottom sediment and two sediment-quality guidelines (table 5). The ODEQ has proposed interim sediment-quality guidelines (Eugene P. Foster, Oregon Department of Environmental Quality, written commun., 1988) for evaluating the potential for adverse effects on water quality. Chemical constituents exceeding the chemical-concentration guidelines would be regarded as having the potential for adversely affecting water quality. The Ontario (Canada) Ministry of the Environment has set provisional sediment-quality guidelines (Washington State Department of Ecology, written commun., 1991) that define three levels of chronic, long-term effects on benthic organisms:

(1) No-Effect Level - - No toxic effects have been observed on aquatic organisms; there is no expected food chain biomagnification, and all water-quality guidelines will be met;

(2) Lowest-Effect Level - - Indicates a level of sediment contamination that can be tolerated by most benthic organisms; and

(3) Severe-Effect Leve1 - Pronounced disturbance of sediment-dwe11ing organisms is expected (contaminant concentration would be detrimental to the majority of benthic species). 
Table 5.--Concentrations of total trace elements in Amazon Creek and A-3 Channe 1 bottom sediment that exceeded either proposed Oregon Department of Environmental Quality (ODEQ) interim sediment-quality guidelines or proposed Ontario Ministry of the Environment provisional sediment-quality guidelines (lowest-effect level)

$[\mathrm{Ag}=$ silver $\mathrm{Cu}=$ copper $\mathrm{Pb}=$ lead $\mathrm{Zn}=$ zinc; $\mathrm{Ni}=$ nickel; $\mathrm{Co}=$ cobalt; $\mathrm{Cd}=$ cadmium; $\mathrm{Cr}=$ chromium; $\mathrm{Hg}=$ mercury; $\mathrm{As}=$ arsenic $;$ and $\mathrm{Mn}=$ manganese. Element concentrations are in parts per million, except for Mn which is in percent. Amazon Creek and A-3 Channel trace-element concentrations for the less-than-63-micrometer plus greater-than-63-micrometer-size fractions have been mathematically composited for the comparison. na = not available, and $*=$ less than both sediment-quality guidelines]

\begin{tabular}{|c|c|c|c|c|c|c|c|c|c|c|c|}
\hline \multirow[b]{2}{*}{ Sampling site } & \multicolumn{11}{|c|}{ Element } \\
\hline & $\overline{\mathrm{Ag}}$ & $\mathrm{Cu}$ & $\mathrm{Pb}$ & $\mathrm{Zn}$ & $\mathrm{Ni}$ & Co & $\mathrm{Cd}$ & $\mathrm{Cr}$ & $\mathrm{Hg}$ & As & $\mathrm{Mn}$ \\
\hline $\begin{array}{l}\text { Proposed ODEQ interim } \\
\text { sediment-quality } \\
\text { guidelines }\end{array}$ & na & 50 & 40 & 250 & na & na & 1.0 & $\begin{array}{l}20- \\
300\end{array}$ & 0.15 & 40 & $\mathrm{n}$ \\
\hline $\begin{array}{l}\text { Ontario Ministry } \\
\text { of Environment } \\
\text { sediment-quality } \\
\text { guidelines }\end{array}$ & 0.5 & 16 & 31 & 120 & 16 & 50 & .6 & 26 & .2 & 6 & .46 \\
\hline $\begin{array}{l}\text { Amazon Creek } \\
\text { Near } 29 \text { th Avenue and }\end{array}$ & & & & & & & & & & & \\
\hline $\begin{array}{l}\text { Hilyard Street } \\
\text { At } 15 \text { th Avenue and }\end{array}$ & * & 84 & 253 & 496 & 64 & 119 & 1.0 & 166 & $*$ & 13 & .58 \\
\hline Madison Street & .6 & 67 & 209 & 413 & 46 & 77 & 1.1 & 124 & .22 & 10 & $*$ \\
\hline At Chambers Steet & $\star$ & 104 & 217 & 575 & 47 & * & 1.2 & 157 & .15 & 17 & $*$ \\
\hline At City View Street & * & 89 & 109 & 325 & 58 & 55 & .7 & 192 & $*$ & 38 & $*$ \\
\hline At Bailey Hill Road & * & 70 & 74 & 245 & 45 & $*$ & $*$ & 174 & $*$ & 42 & $*$ \\
\hline $\begin{array}{l}\text { At Bertleson Road } \\
\text { Upstream from Royal }\end{array}$ & * & 62 & 36 & 179 & 69 & 83 & $*$ & 124 & * & 118 & $*$ \\
\hline Avenue & * & 45 & 37 & 176 & 39 & 76 & * & 76 & * & 39 & $*$ \\
\hline $\begin{array}{l}\text { A-3 Channe } 1 \\
\text { Above Bertleson }\end{array}$ & & & & & & & & & & & \\
\hline $\begin{array}{l}\text { Slough } \\
\text { Near mid-Bertleson }\end{array}$ & 2.4 & 94 & 190 & 795 & 56 & * & 3.0 & 118 & 2.96 & 12 & * \\
\hline Slough & 1.4 & 83 & 185 & 780 & 65 & * & 1.7 & 108 & 2.25 & 17 & * \\
\hline At Bertleson Road & .6 & 60 & 100 & 520 & 53 & * & 1.1 & 82 & .89 & 19 & * \\
\hline At Terry Road & $*$ & 34 & $*$ & 125 & 19 & $*$ & $*$ & 88 & $*$ & 19 & $*$ \\
\hline
\end{tabular}


Eleven of the 13 trace elements determined to be enriched in bottom sediment (silver, copper, lead, zinc, nickel, cobalt, cadmium, chromium, mercury, arsenic, and manganese) exceeded either the ODEQ proposed interim sediment-quality guidelines or the Ontario Ministry of the Environment provisional lowest-effect level of sedimentquality guidelines at one or more of the Amazon Creek Basin sites (table 5). Guidelines have not been proposed for antimony and titanium, so their potential impacts to the biota could not be evaluated. Copper, lead, zinc, nickel, chromium, and arsenic exceeded the sediment-quality guidelines at most sites sampled, whereas cadmium exceeded guidelines at more than one-half of the sites sampled (table 5). Cobalt exceeded sediment-quality guidelines only in Amazon Creek; but silver and mercury exceeded guidelines predominantly in A-3 Channel. Manganese exceeded guidelines at only one site (Amazon Creek $n r$ 29th and Hilyard Street). Median values for the mathematically composited concentrations for silver, zinc, and mercury in A-3 Channel were from 2 to 12 times the median values in Amazon Creek ( $t a b l e ~ 5)$. The median value for arsenic in Amazon Creek was about twice that determined for A-3 Channel.

\section{Comparison of Organic Compounds and Trace Elements in Bottom Material with other Study Areas}

A literature search was made for other USGS studies in the Willamette River Basin containing water-chemistry data that could be compared to the Amazon Creek Basin findings. No data could be found to compare with for organic compounds analyzed in whole-water samples, but comparative data for trace elements and organic compounds in bottom sediment were available.

Concentrations of arsenic, cadmium, chromium, copper, lead, mercury, nickel, and zinc in $<63-\mu \mathrm{m}-\mathrm{size}$ bottom sediment of Amazon Creek Basin were compared to concentrations in $<63-\mu \mathrm{m}-\mathrm{size}$ bottom sediment observed during a 1988 Johnson Creek study (Edwards, 1992), and in $<20-\mu \mathrm{m}$-size bottom sediment observed during a 1973 study in the Portland Harbor of the Willamette River (Rickert and others, 1977) [figs. 3 and 4]. Natural background lines represented by Willamette River bottom-sediment breakpoint values (table 4) also were plotted in figures 3 and 4 for comparison. With the exception of cadmium concentrations in Johnson Creek, Amazon Creek traceelement concentrations were predominantly larger than those observed in Johnson Creek and the Willamette River. The median concentration of cadmium in Johnson Creek was similar to that observed in the Amazon Creek Basin. However, the largest element concentrations of chromium, copper, lead, and nickel in Johnson Creek bottom sediment approached or exceeded the largest concentrations observed in Amazon Creek Basin. Generally, trace-element concentrations in the smaller Willamette tributaries of Amazon Creek and Johnson Creek were much larger than those observed in the larger Willamette River main-stem sites in the Portland Harbor. This observation of larger element concentrations in smaller tributaries also has been noted in the Yakima River Basin (Greg Fuhrer, U.S. Geological Survey, oral commun., 1991) and is thought to result from sediment dilution of enriched element materials by background materials containing much lower element concentrations. 
A) ARSENIC

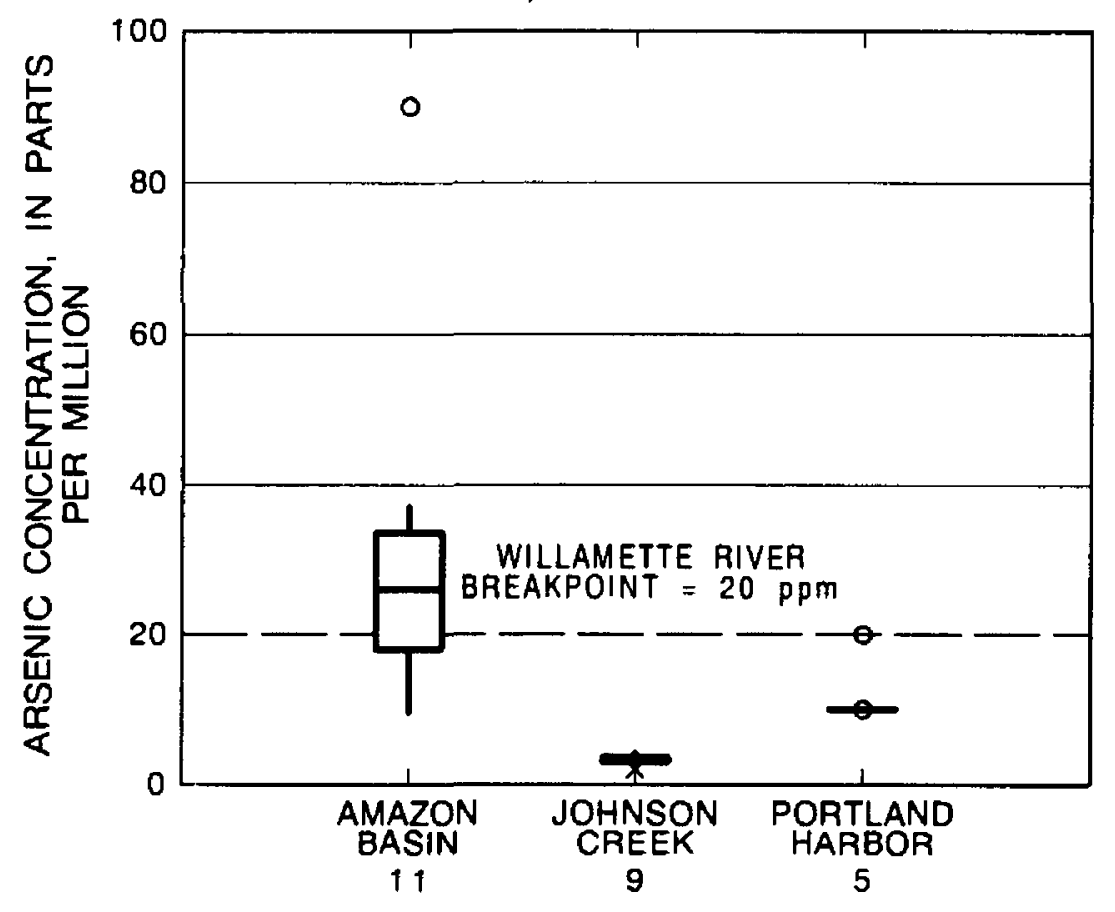

C) CHROMIUM

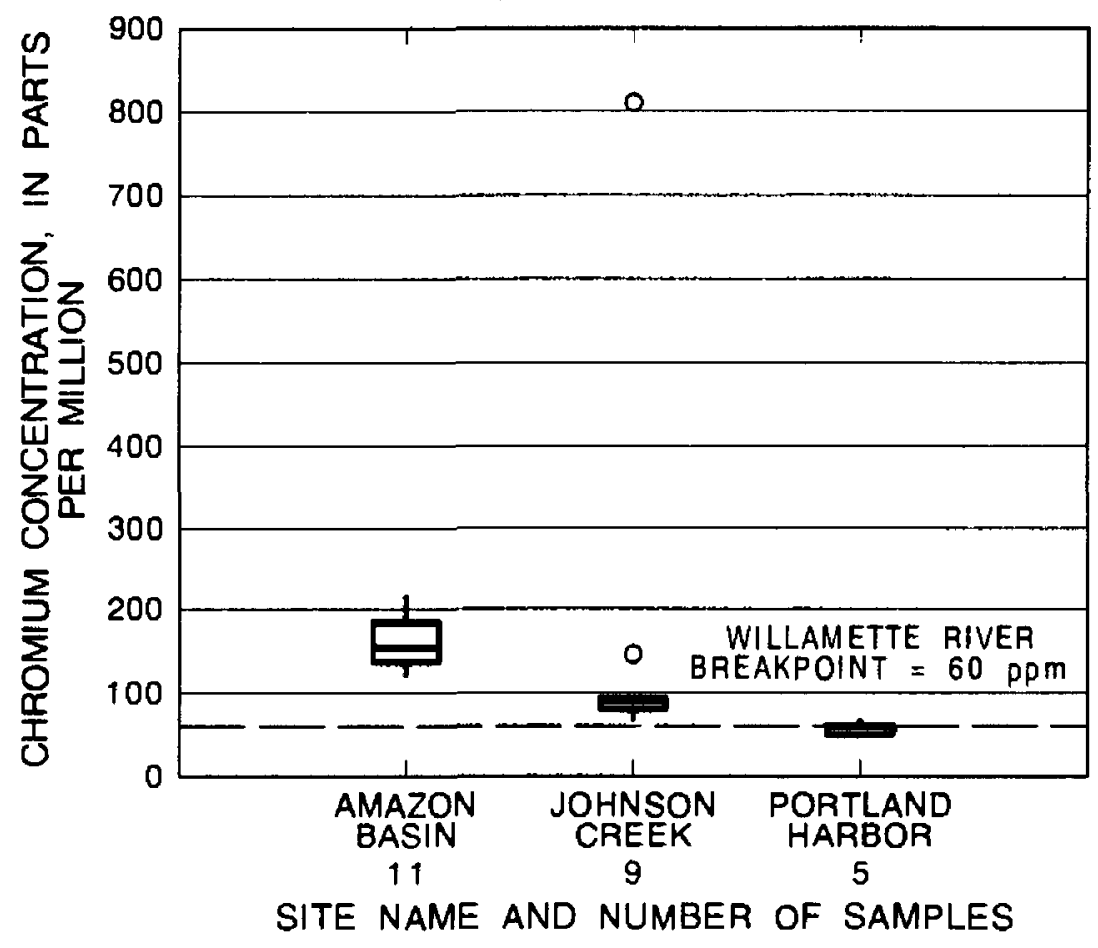

B) CADMIUM

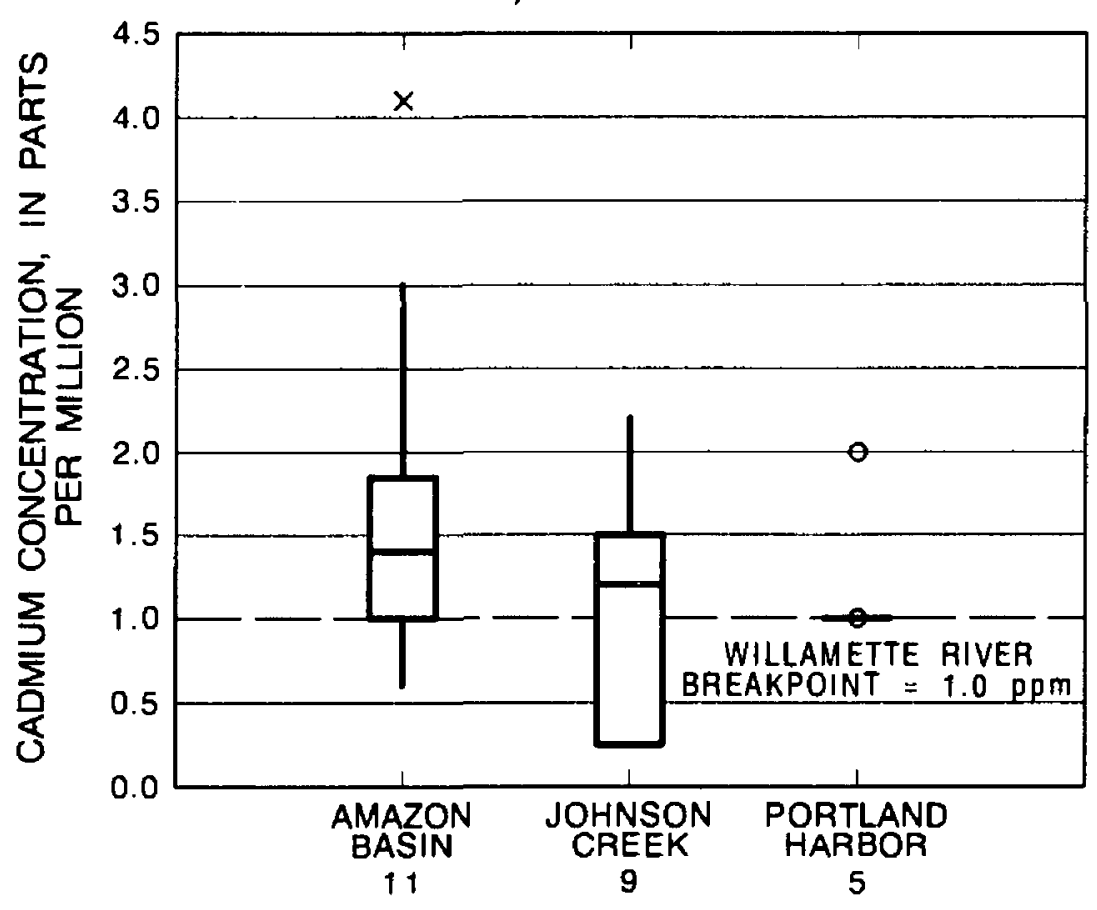

D) COPPER

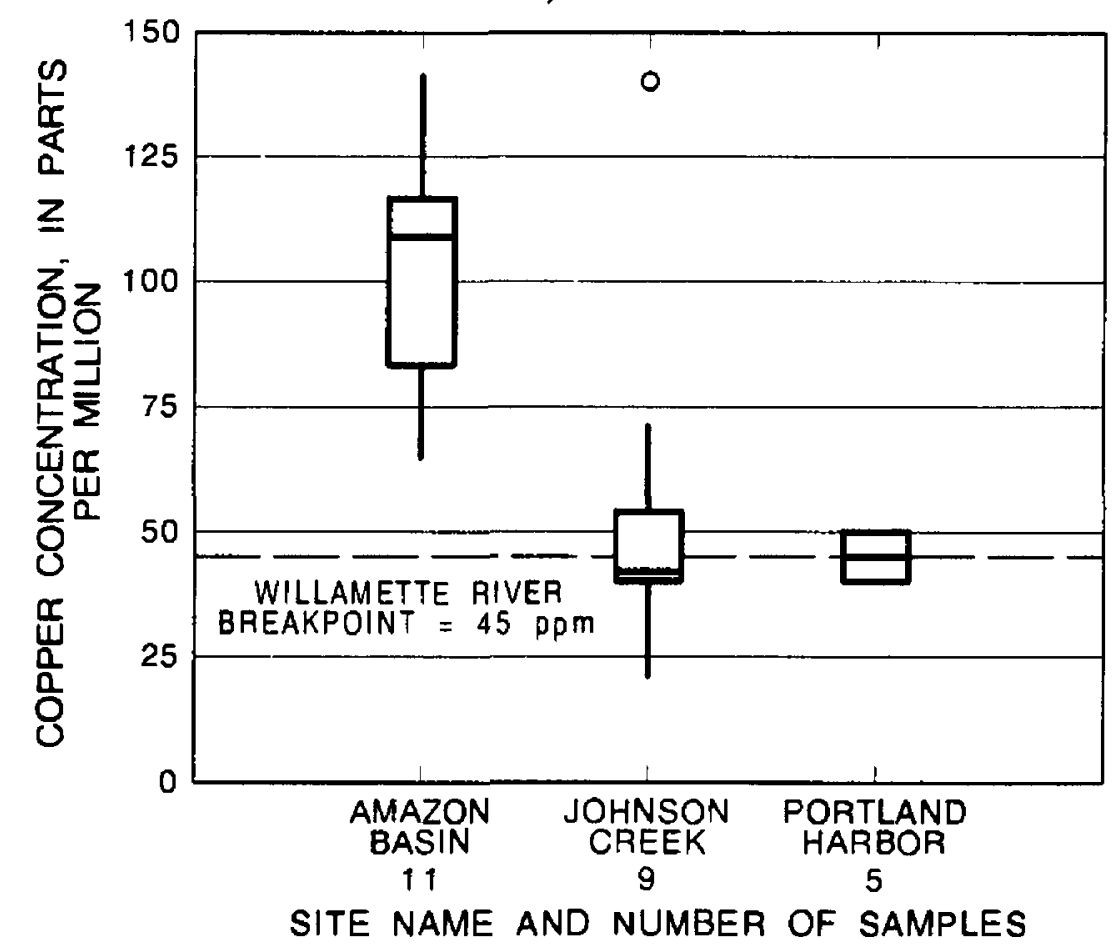

\section{EXPLANATION}

Interquartile range equals the value of the 75 th

percentile minus the value of the 25 th percentile.

- More than 3 times the interquartile range from the 75-percentile value

$x \quad 1.5$ to 3 times the interquartile range from the 75-percentile value

Less than 1.5 times the interquartile range from the 75-percentile value

75-percentile value

Median value

25-percentile value

Less than 1.5 times the interquartile range from the 25-percentile value

$\times \quad 1.5$ to 3 times the interquartile range from the 25-percentile value

Figure 3. Boxplots of trace-element concentrations in bottom sediment from Amazon Creek Basin, Johnson Creek, and Portland Harbor. Breakpoint value represents division between natural background and enriched element concentrations. 


\section{A) LEAD}

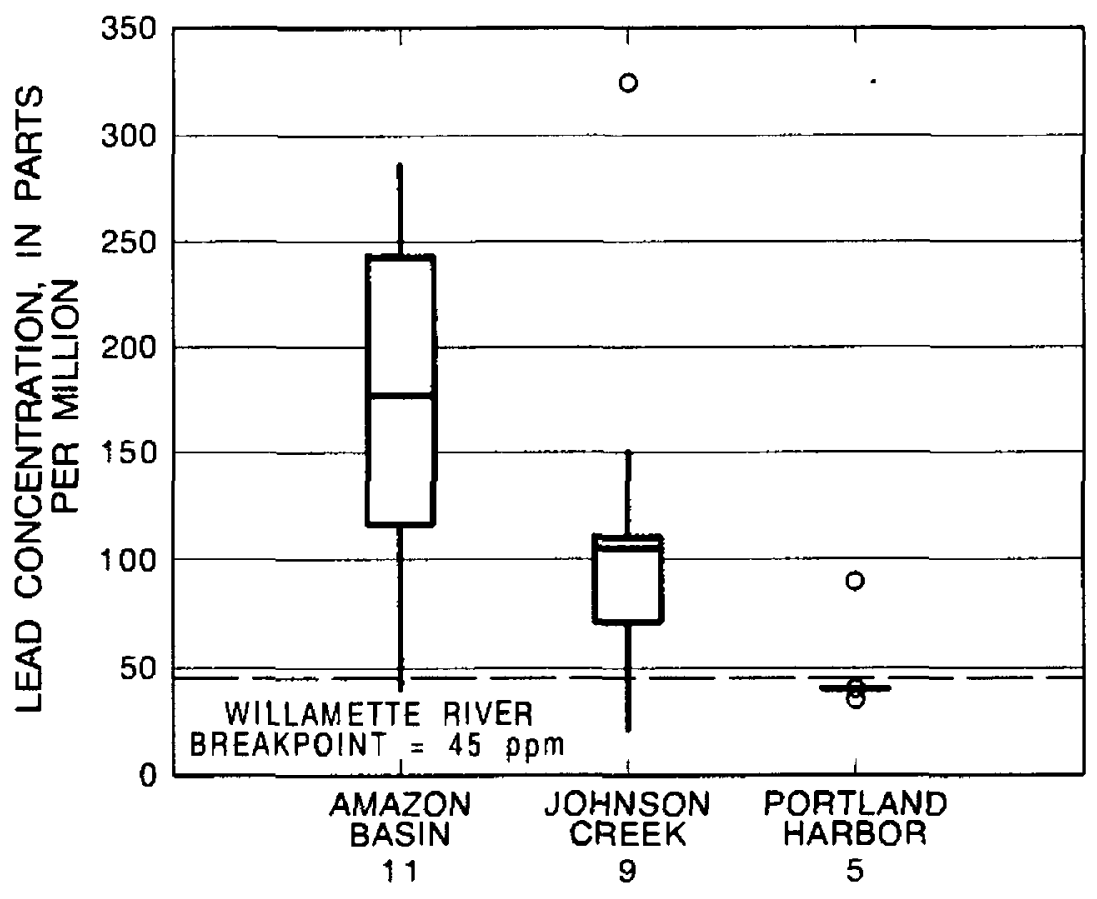

C) NICKEL

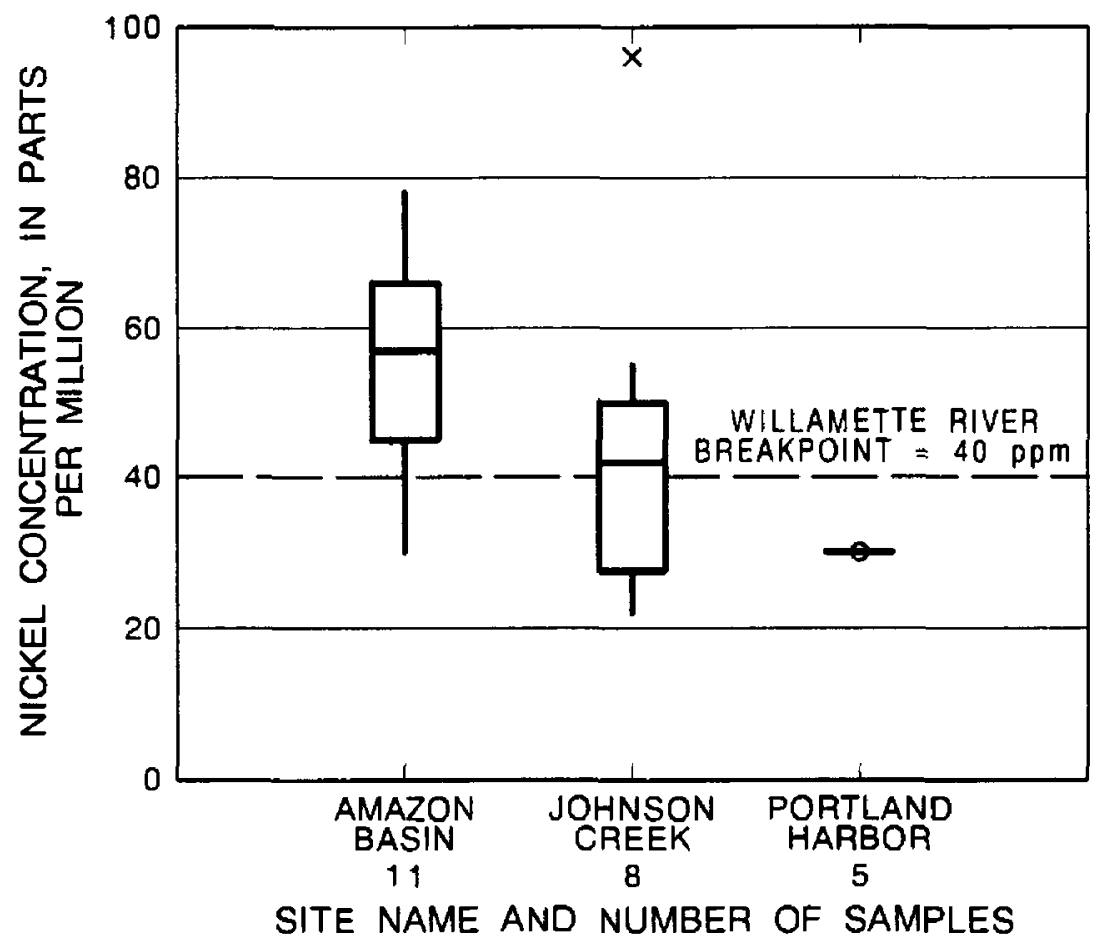

B) MERCURY

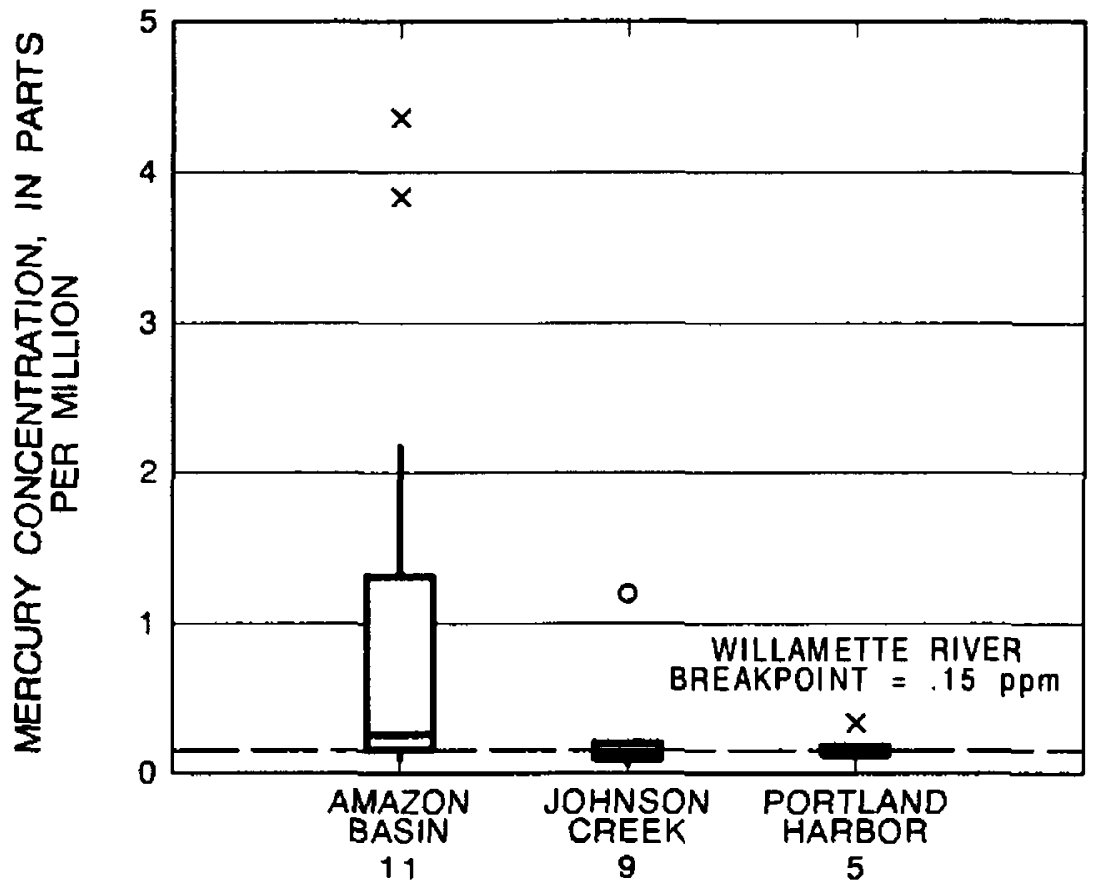

D) ZINC

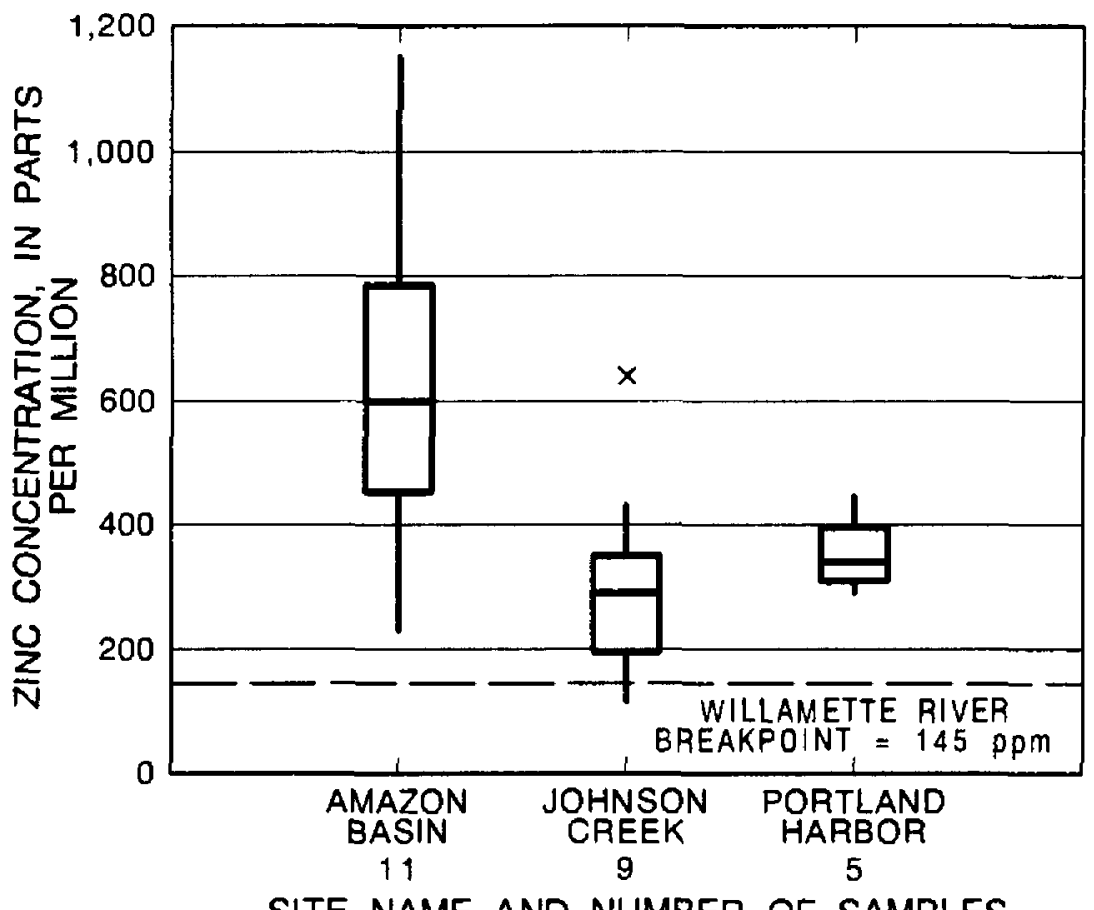

EXPLANATION

Interquartile range equals the value of the 75 th

percentile minus the value of the 25th percentile.

- More than 3 times the interquartile range from the 75 -percentile value

$\times \quad 1.5$ to 3 times the interquartile range from the 75 -percentile value

Less than 1.5 times the interquartile range from the 75-percentile value

75-percentile value

Median value

25-percentile value

Less than 1.5 times the interquartile range from the 25-percentile value

- More than 3 times the interquartile range from the 25-percentile value

Figure 4. Boxplots of trace-element concentrations in Amazon Creek Basin, Johnson Creek, and Portland Harbor. Breakpoint value represents division between natural background and enriched element concentrations. 
Amazon Creek Basin organic-compound concentrations of chlordane, DDT plus metabolites, dieldrin, PCBs, naphthalene, pryene, and bis(2ethyl-hexyl)phthalate in $<63-\mu \mathrm{m}$-size bottom sediment were compared to organic-compound concentrations observed in bulk bottom sediment during a 1983 study of the Portland Harbor of the Willamette River (Fuhrer, 1989) [figs. 5 and 6]. A comparison with the Portland Harbor data is presumed valid because, with the exception of one site, bottom-sediment samples from the Portland Harbor were predominantly silt-clay $(<63 \mu \mathrm{m})$ in size. Sufficient DDT plus metabolite data were available for $<63-\mu \mathrm{m}-\mathrm{size}$ bottom sediment in Johnson Creek Basin for comparative purposes (Edwards, 1992). In most cases, organic-compound concentrations in Amazon Creek Basin were larger than those observed in Portland Harbor. Median concentration of DDT plus metabolites in Johnson Creek was similar to that observed in the Amazon Creek Basin. The largest values for DDT plus metabolites in Johnson Creek and naphthalene in Portland Harbor exceeded those observed in the Amazon Creek Basin. It is believed that the smaller organic-compound concentrations observed in the Portland Harbor, as compared to those in Amazon Creek, is the result of sediment dilution by background materials containing smaller concentrations of organic compounds.

\section{SUMMARY AND CONCLUSIONS}

In September 1990, the U.S. Geological Survey, in cooperation with the Lane Council of Governments and the City of Eugene, collected whole-water and bottom-sediment samples in Amazon Creek and a tributary to Amazon Creek (A-3 Channel). Whole-water and bottomsediment samples were analyzed for different classes of organic compounds, including many compounds from the EPA priority pollutant 1ist. In addition, bottom-sediment samples were analyzed for trace elements typically associated with urban runoff.

Five chlorophenoxy-acid herbicides (2,4-D, 2,4,5-T, silvex, picloram, and dicamba), one organophosphorus insecticide (diazinon), and three semivolatile priority pollutants (pentachlorophenol, naphthalene, and pyrene) were found in whole-water samples from the Amazon Creek Basin. Of the chlorophenoxy-acid herbicides detected, only 2,4-D concentrations were at levels substantially above reporting limits. Diazinon concentrations in Amazon Creek and A-3 Channel exceeded the 1972 National Academy of Sciences maximum concentration of $0.009 \mu \mathrm{g} / \mathrm{L}$ recommended for the protection of freshwater aquatic life. Semivolatile priority pollutants in whole water were detected at only A-3 Channel sites. A concentration of pentachlorophenol at one site in A-3 Channel exceeded EPA's chronic toxicity concentration of $3.5 \mu \mathrm{g} / \mathrm{L}(\mathrm{pH}=6.5)$ established for the protection of freshwater aquatic life. Naphthalene and pyrene were detected at only one A-3 Channel site. Pyrene at that concentration exceeds the 1-in-100,000-lifetime-cancer-risk exposure to the polynuclear aromatic hydrocarbon from ingestion of contaminated water and contaminated aquatic organisms. 
A) CHLORDANE

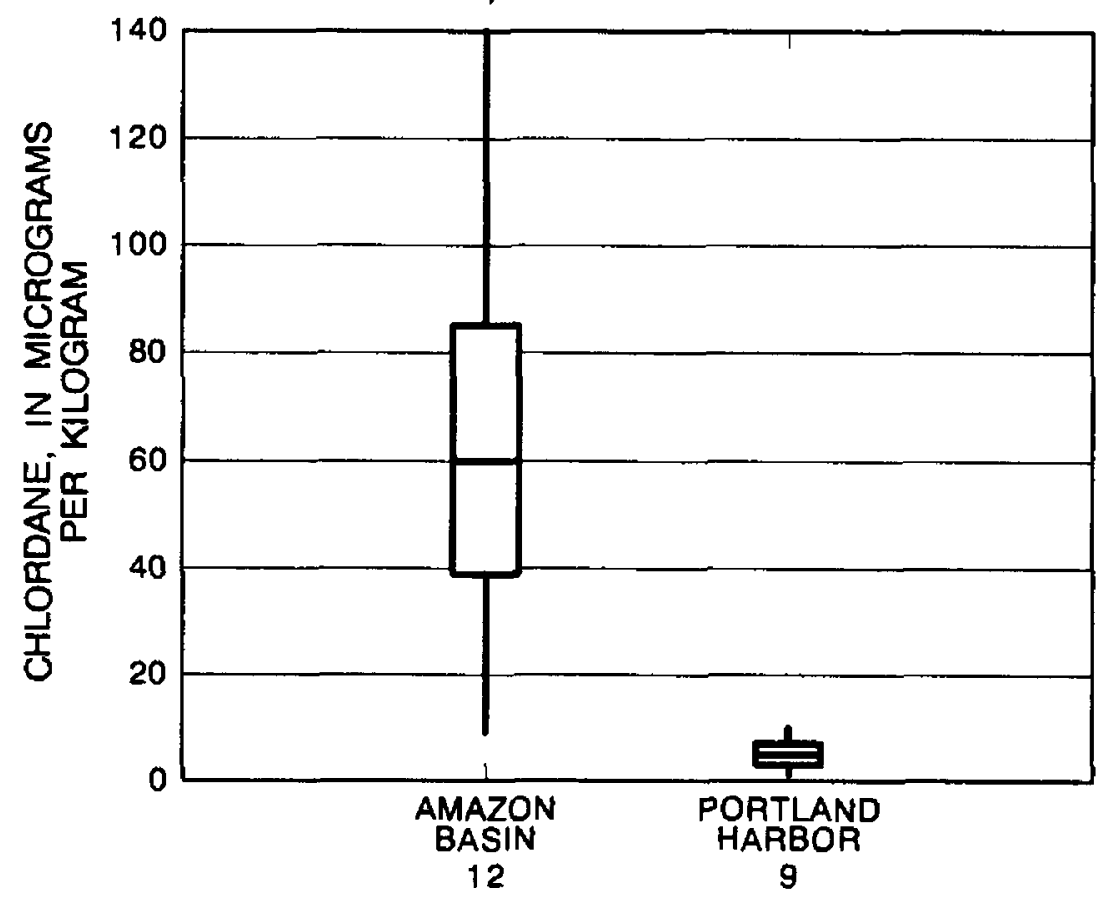

C) DIELDRIN

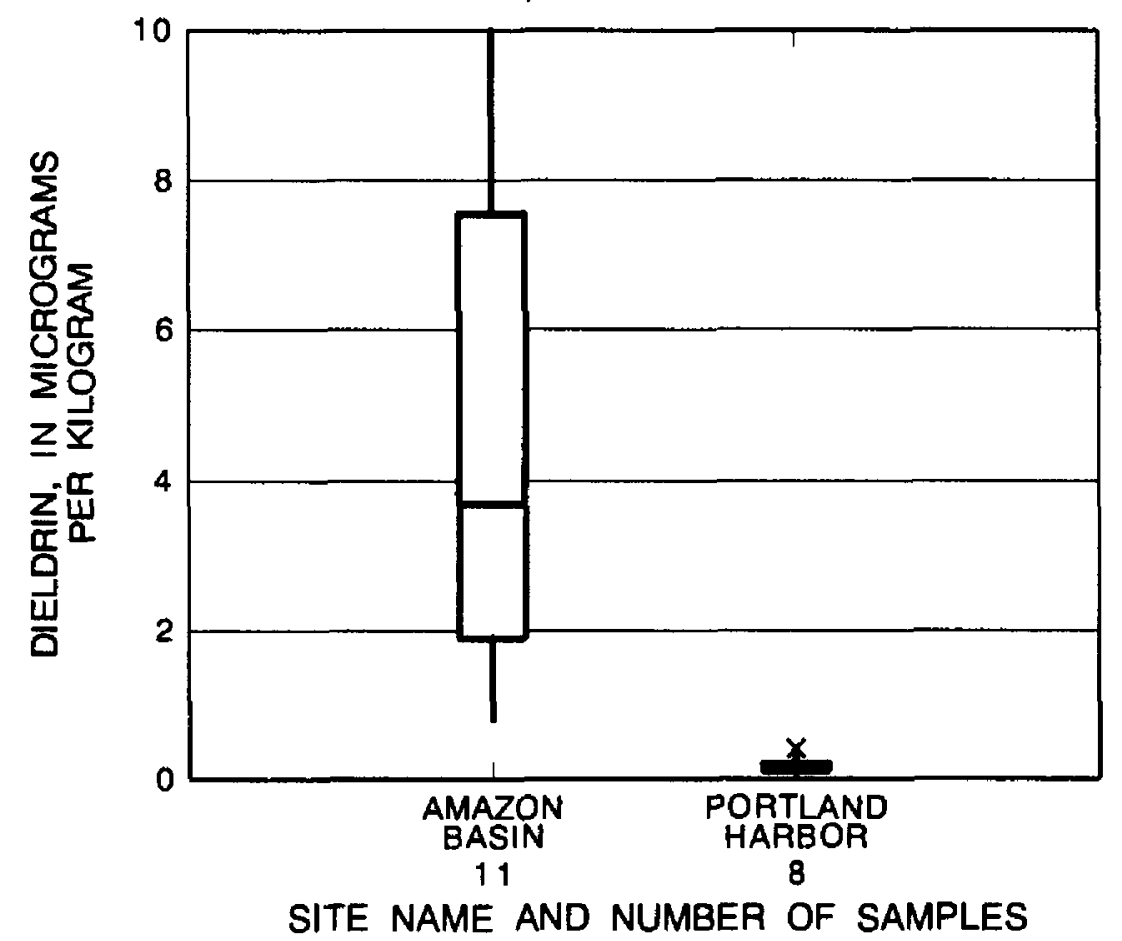

B) DDT PLUS METABOLITES

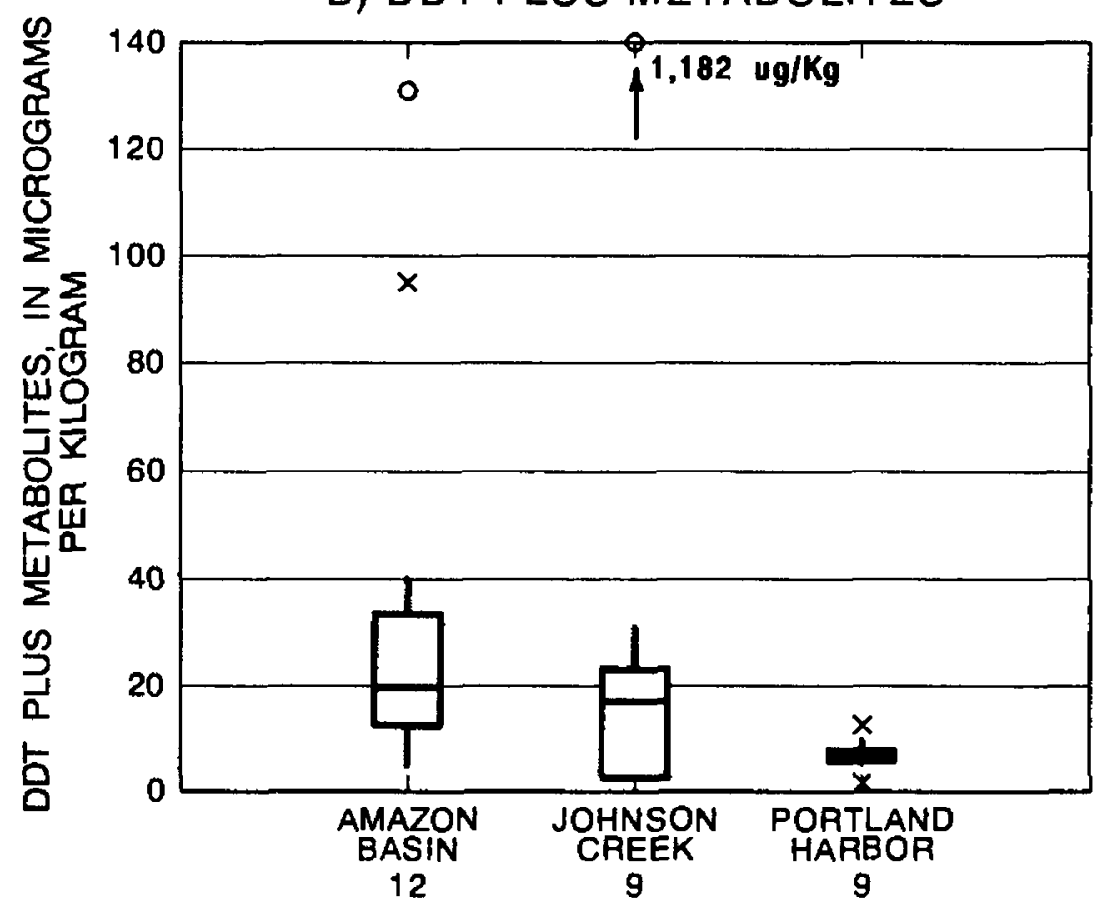

D) POLYCHLORINATED BIPHENYLS

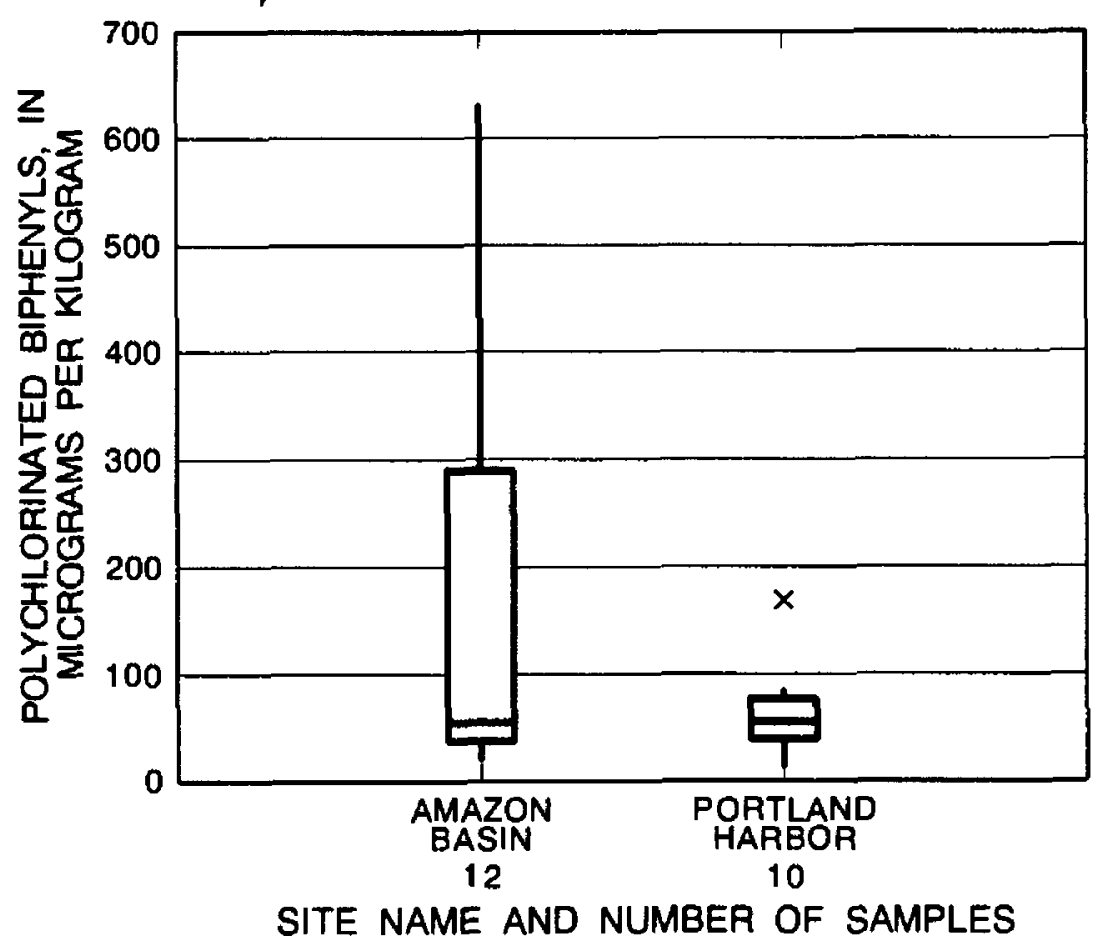

\section{EXPLANATION}

Interquartile range equals the value of the 75th

percentile minus the value of the 25 th percentile.

- More than 3 times the interquartile range from the 75-percentile value

$\times \quad 1.5$ to 3 times the interquartile range from the 75 -percentile value

Less than 1.5 times the interquartile range from the 75-percentile value

75-percentile value

Median value

25-percentile value

Less than 1.5 times the interquartile range from the 25-percentile value

$\times \quad 1.5$ to 3 times the interquartile range from the 25 -percentile value

Figure 5. Boxplots of organochlorine concentrations in bottom sediment from Amazon Creek Basin and Portland Harbor. 
A) NAPHTHALENE

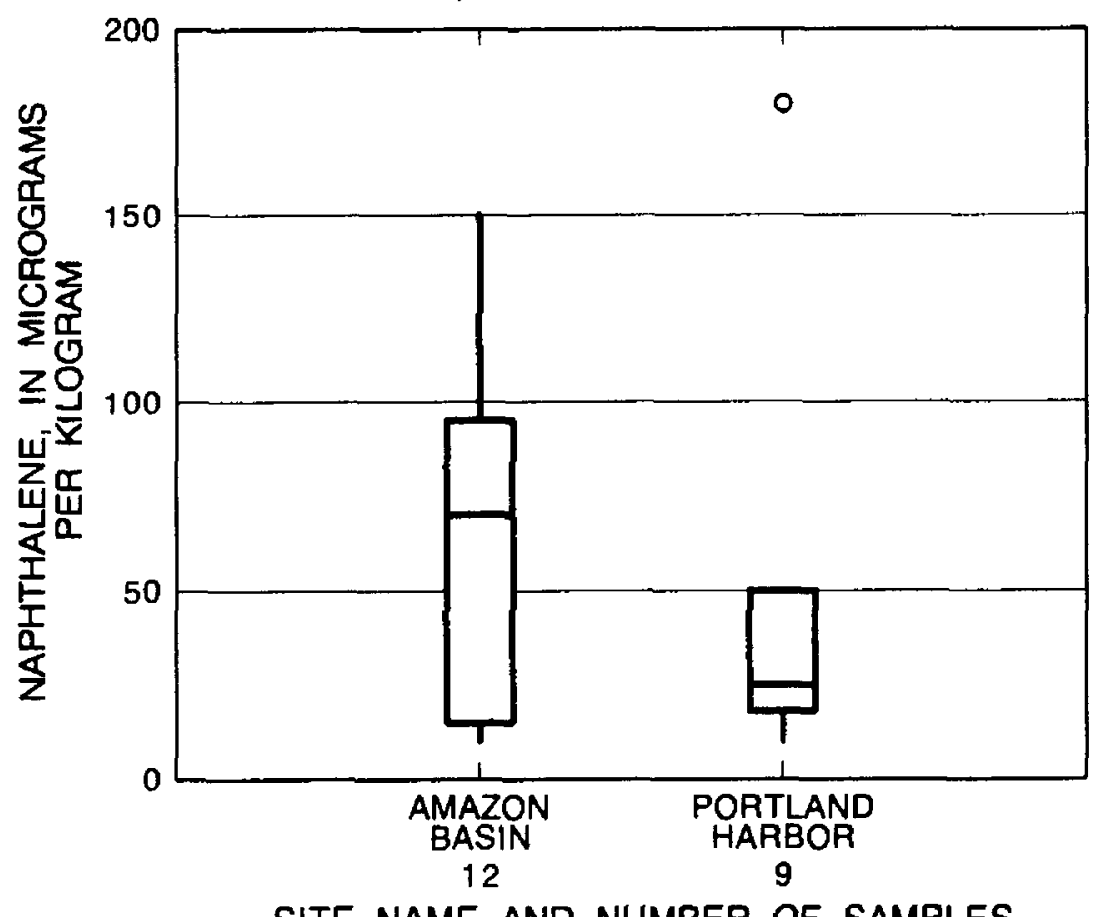

SITE NAME AND NUMBER OF SAMPLES

C) BIS(2-ETHYL-HEXYL)PHTHALATE

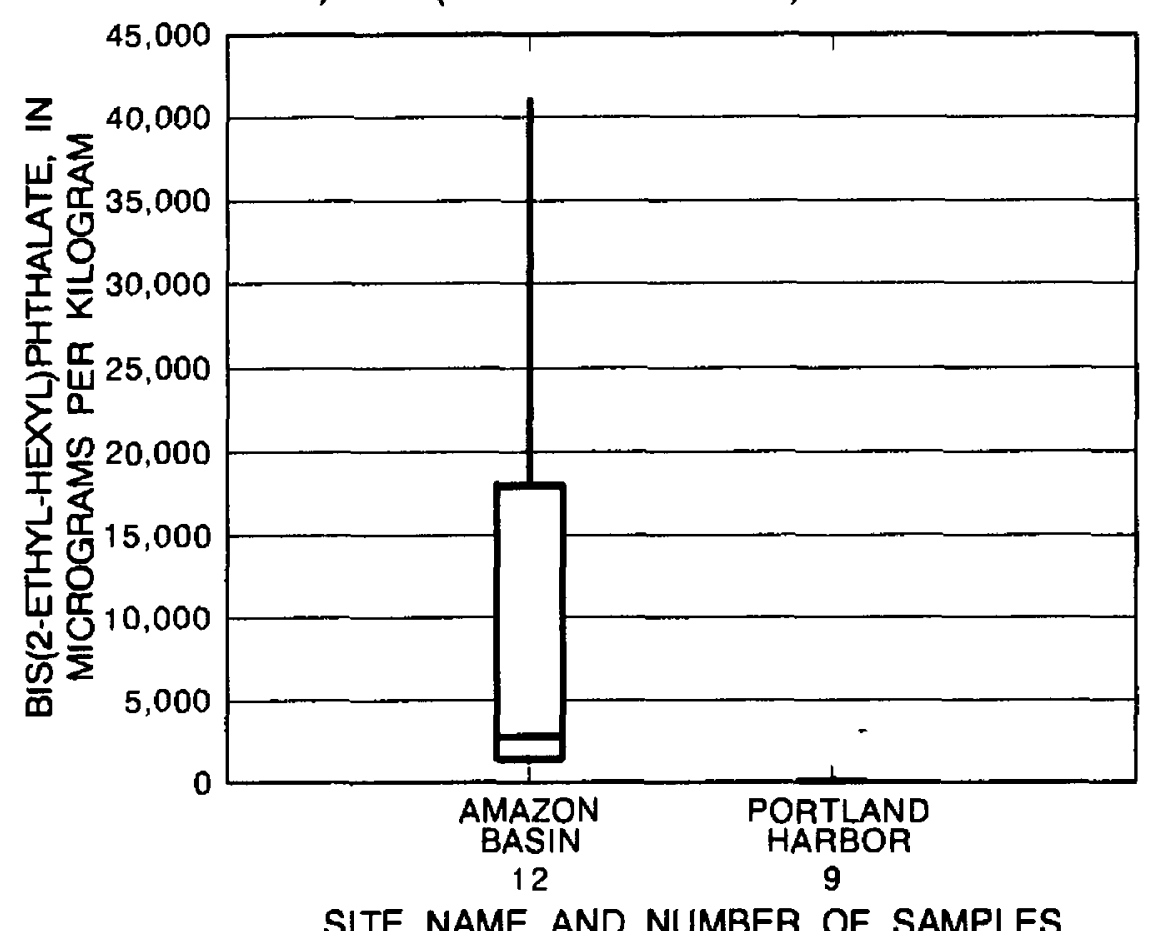

B) PYRENE

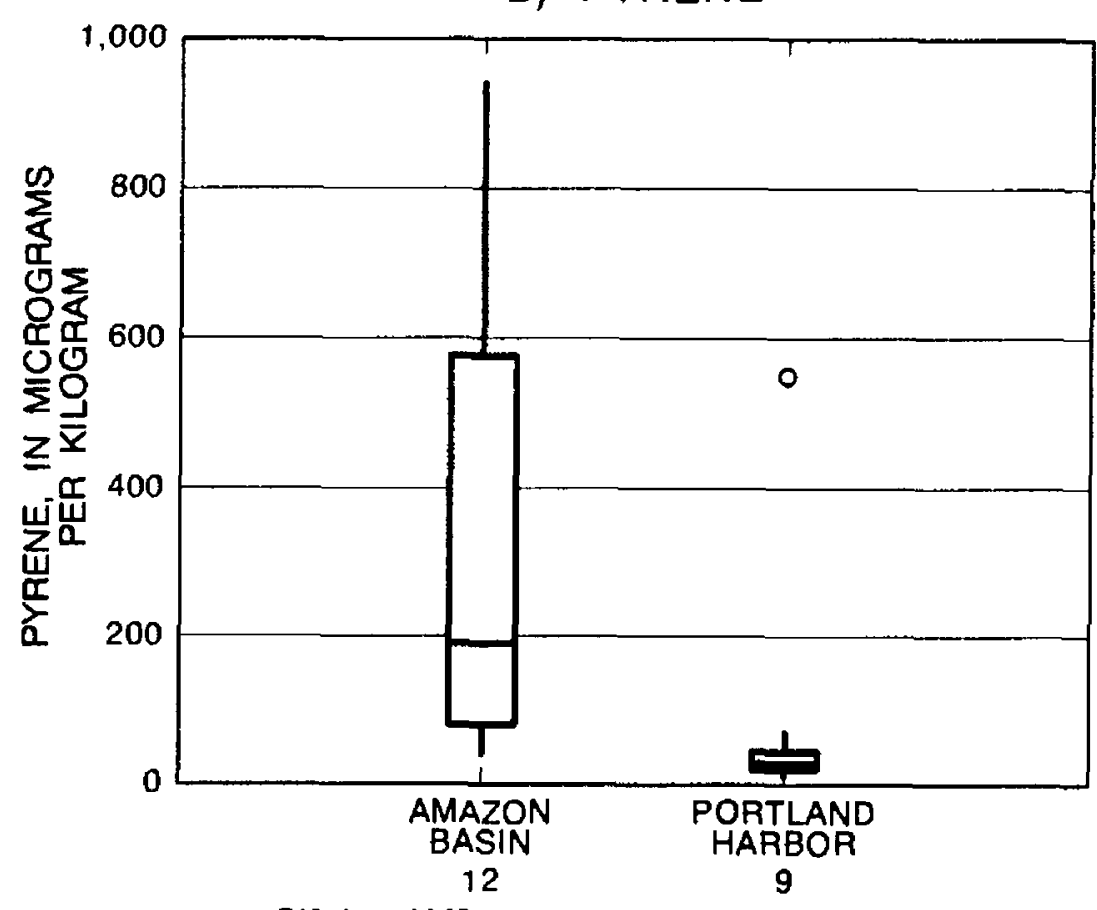

SITE NAME AND NUMBER OF SAMPLES

\section{EXPLANATION}

Interquartile range equals the value of the 75th percentile minus the value of the 25 th percentile.

- More than 3 times the interquartile range from the 75-percentile value

Less than 1.5 times the interquartile range from the 75-percentile value

75-percentile value

Median value

25-percentile value

Less than 1.5 times the interquartile range from the 25-percentile value

Figure 6. Boxplots of semivolatile concentrations in bottom sediment from Amazon Creek Basin and Portland Harbor. 
Eight organochlorine compounds (chlordane, DDT, DDE, DDD, dieldrin, endrin, heptachlor epoxide, and PCBs) and 24 of 54 semivolatile priority pollutants (including pentachlorophenol, naphthalene, and pyrene) were detected in bottom sediment at some or all sites sampled in the Amazon Creek Basin. PCB concentration at one site in Amazon Creek exceeded the proposed ODEQ interim bulksediment-quality guideline of $500 \mu \mathrm{g} / \mathrm{kg}$. Twenty-three of the 24 semivolatile priority pollutant compounds detected in the Amazon Creek Basin were found at one or more of the sites located in A-3 Channel; concentrations for 18 of the compounds observed (including pentchlorophenol) were largest in A-3 Channel. Pentachlorophenol was detected only in bottom sediment and whole-water samples collected from A-3 Channel. During a 1992 sampling, trace amounts of polychlorinated dibenzo-dioxins (PCDDs) and polychlorinated dibenzofurans were detected in bottom sediment of A-3 Channel.

Concentrations in bottom sediment of silver, copper, lead, zinc, nickel, cobalt, cadmium, chromium, mercury, arsenic, antimony, manganese, and titanium from Amazon Creek and A-3 Channel exceeded the greater of the Willamette River bottom-sediment breakpoint values or the upper 95-percent baseline-confidence limits for soils from the Western United States. Concentrations in bottom sediment of silver, copper, lead, zinc, nickel, cobalt, cadmium, chromium, mercury, arsenic, and manganese also exceeded either the ODEQ proposed interim sediment-quality guidelines or the Ontario Ministry of the Environment provisional lowest-effect-level sediment-quality guidelines for aquatic life at one or more sites in the Amazon Creek Basin. Guidelines have not been proposed for antimony and titanium, so their potential affect on the biota was not evaluated. 


\section{REFERENCES CITED}

City of Eugene, 1987, Amazon channe1 study - Draft: Department of Public Works, 65 p.

Edwards, T.K., 1992, Water-quality and flow data for the Johnson Creek Basin, April 1988 to January 1990: U.S. Geological Survey Open-File Report 92-73, 29 p.

Fuhrer, G.J., 1989, Quality of bottom materials and elutriates in the lower Willamette River, Portland Harbor, Oregon: U.S. Geological Survey Water-Resources Investigations Report 89-4005, 30 p.

Horowitz, A.J., 1991, A primer on sediment-trace element chemistry Second edition: Chelsea, Michigan, Lewis Publishers, Inc., $136 \mathrm{p}$.

Jordan Advent and Associates, 1977, Urban stormwater analysis EugeneSpringfield Metropolitan area, Section 208 Wastewater Management Program, $160 \mathrm{p}$.

Lane Council of Governments, 1981, National urban runoff program Eugene-Springfield Metropolitan area, $158 \mathrm{p}$.

1983, Fern Ridge clean lakes study - final report: January $1983,118 \mathrm{p}$. $84 \mathrm{p}$.

1991, West Eugene wetlands, special area study; Draft plan,

Luoma, S.N., 1983, Bioavailability of trace elements to aquatic organisms - A review: The Science of the Total Environment, v. 28, p. $1-22$.

National Academy of Sciences, 1973, Water quality criteria 1972: Washington, D.C., Ecological Research Series, EPA-R3-73-033, National Academy of Engineering, 594 p.

Oregon Department of Environmental Quality, 1988, 1988 Oregon statewide assessment of nonpoint sources of water pollution: Planning \& Monitoring Section, Water Quality Division, 292 p.

1989, Nonpoint source statewide management plan for Oregon: Planning \& Monitoring Section, Water Quality Division, $165 \mathrm{p}$.

1990,1990 Water quality status assessment report: 305 b Report, Water Quality Division, 297 p.

Rickert, D.A., Kennedy, V.C., McKenzie, S.W., and Hines, W.G., 1977, A synoptic survey of trace metals in bottom sediments of the Willamette River, Oregon: U.S. Geological Survey Circular 715-F, $27 \mathrm{p}$.

Shacklette, H.T., and Boerngen, J.G., 1984, Element concentrations in soils and other surficial materials of the conterminous United States: U.S. Geological Survey Professional Paper 1270, 105 p. 
U.S. Environmental Protection Agency, 1986, Quality criteria for water - 1986 (two updates): Washington, D.C., EPA 440/5-86-001, May 1986.

1988, Interim sediment criteria values for nonpolar hydrophobic organic contaminants: Washington, D.C., SCD\#17, May 1988.

1990, Internal Document-Subject: Tables of criteria maximum concentrations, final chronic values, Koc values and acute and chronic sediment quality criteria values: Narragansett, Rhode Island, Office of Research and Development, January 7, 1990.

Wershaw, R.L., Fishman, M.J., Grabbe, R.R., and Lowe, L.E., 1987, Methods for the determination of organic substances in water and fluvial sediment: U.S. Geological Survey, Techniques of WaterResources Investigations, Book 5, Chapter A3, 80 p. 
S U P P LE MENTAL D A T A TA B L E S 
Table 6.--Concentrations of chlorophenoxy-acid herbicides in whole water, Amazon Creek Basin. September 1990

[Herbicide concentrations in micrograms per liter;

$2,4,-D=2,4-$ dichlorophenoxyacetic acid;

$2,4,5-T=2,4,5$-trichlorophenoxyacetic acid;

$2,4-\mathrm{DP}=2-(2,4-\mathrm{dichlorophenoxy})$-propionic acid;

" $-"$ = not analyzed; $<=$ less than

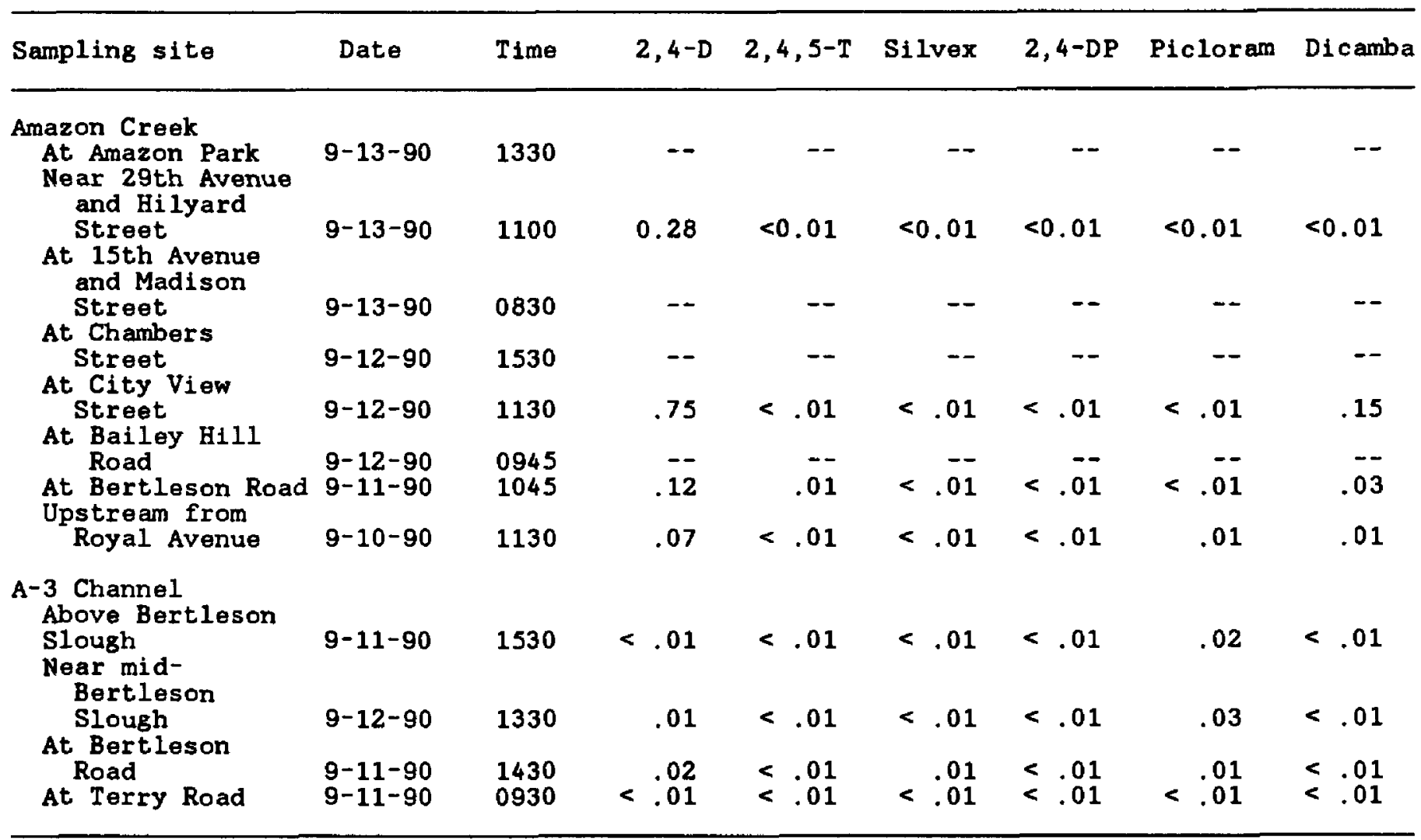

Table 7.--Concentrations of organophosphorus insecticides in whole water, Amazon Creek Basin, September 1990

[Insecticide concentrations in micrograms per liter; DEF = S,S,S-Tributylphosphorotrithioate; $"=-"$ = not analyzed; $<$ = less than]

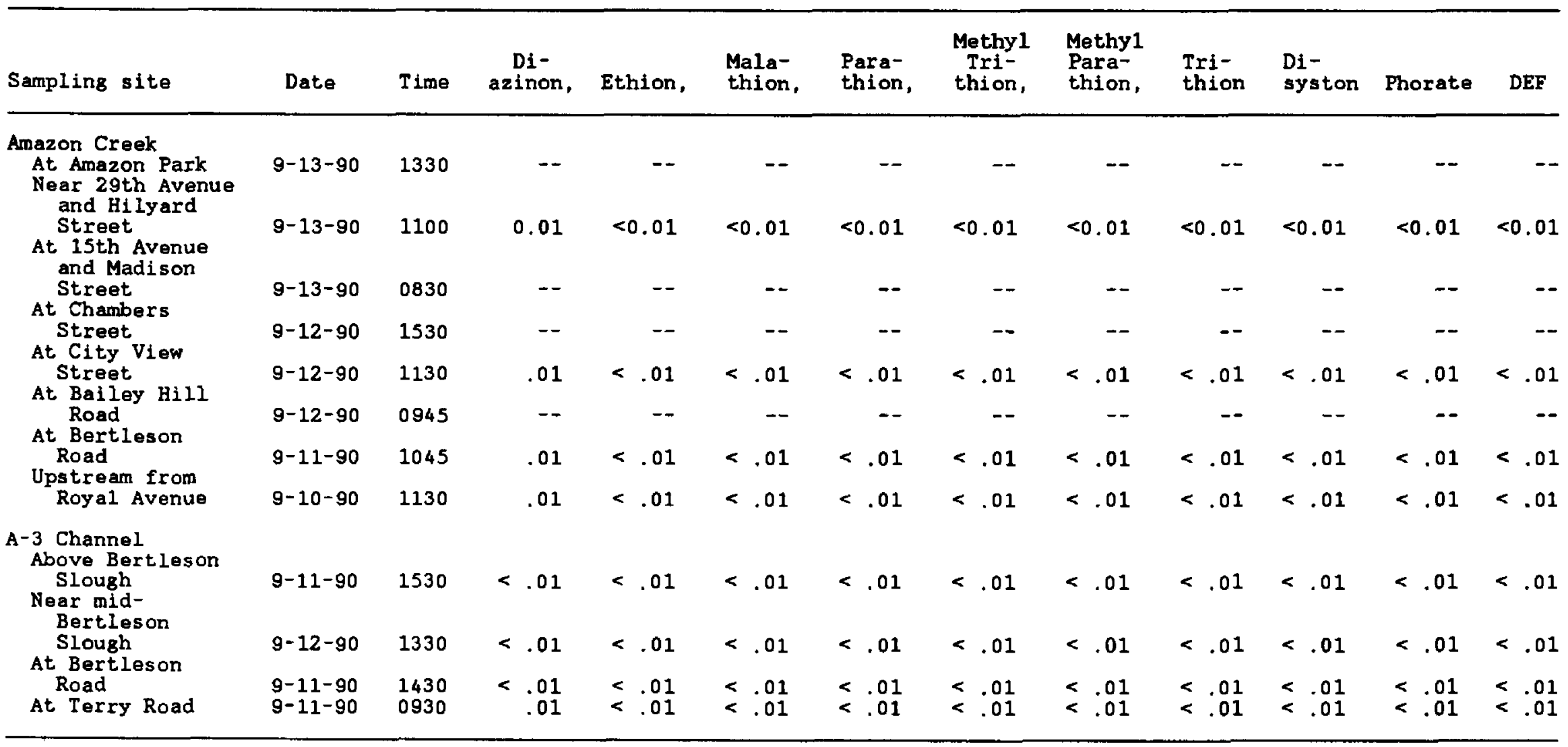


Table 8.--Concentrations of semivolatile priority pollutants in whole water. Amazon Creek Basin. September 1990

[Priority pollutant concentrations in micrograms per liter: "--" = not analyzed; < less than]

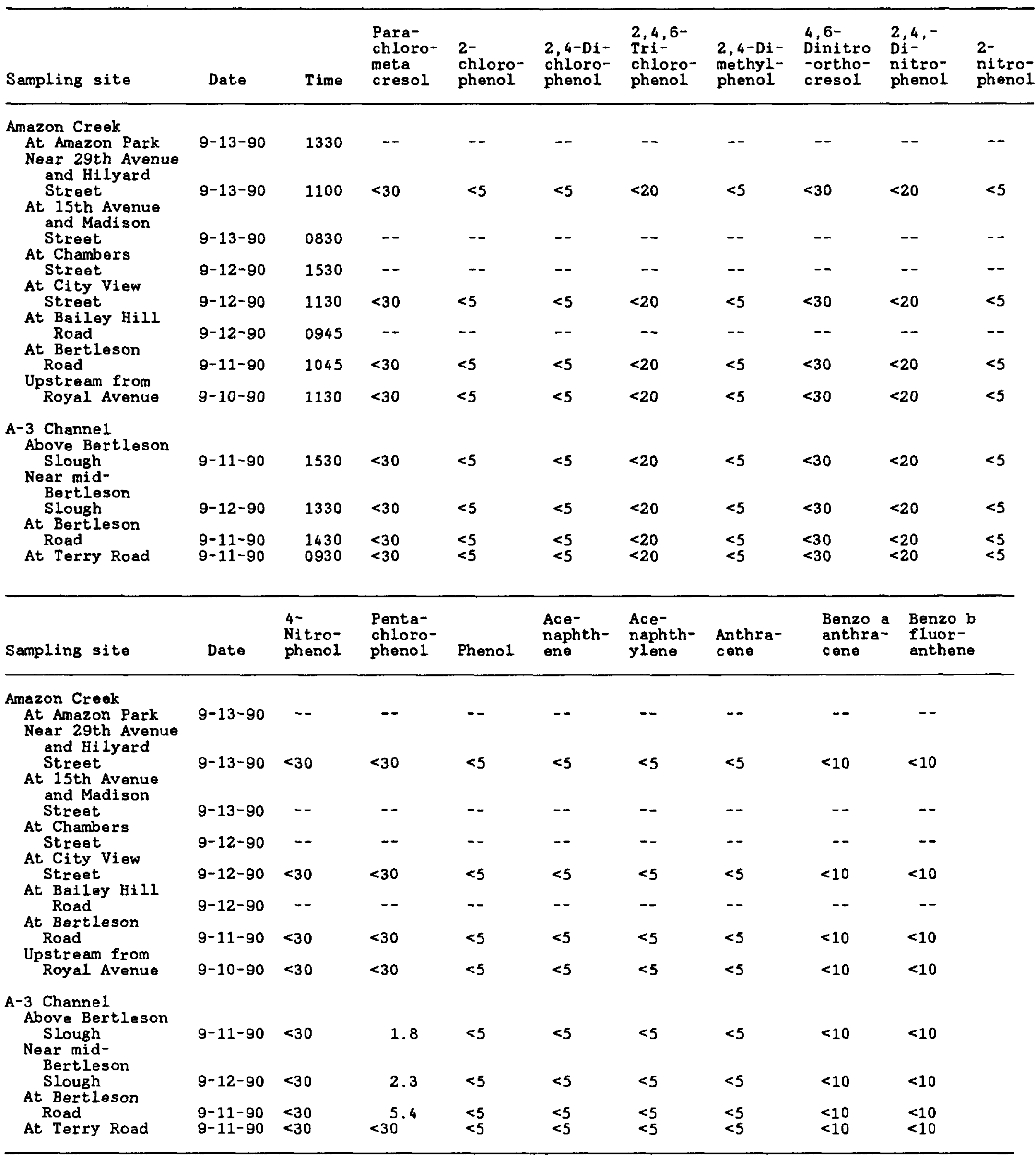


Table 8. -Concentrations of semivolatile priority pollutants in

whole water, Amazon Creek Basin, September 1990--Continued

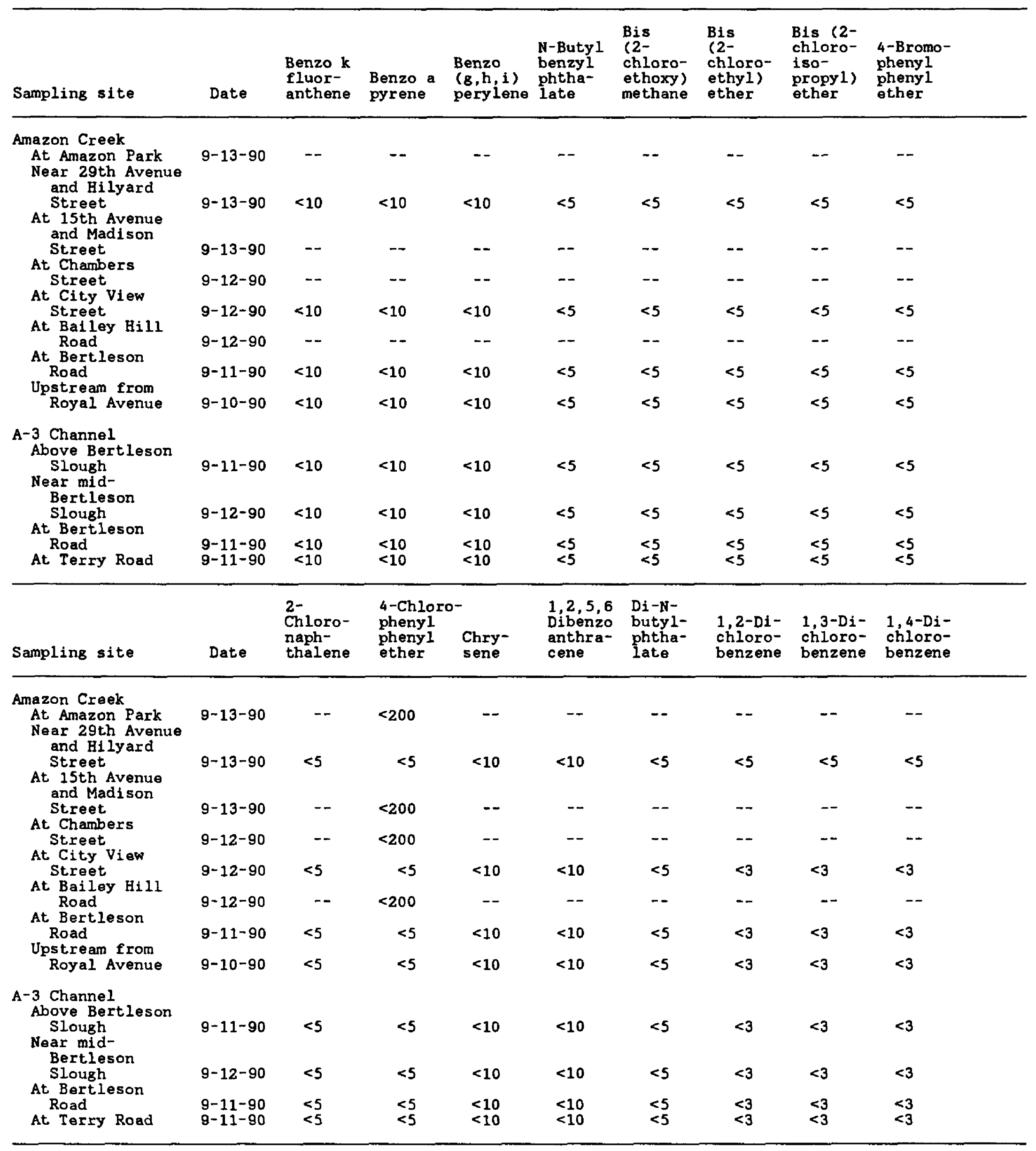


Table 8.--Concentrations of semivolatile priority pollutants in whole water Amazon Creek Basin September 1990--Continued

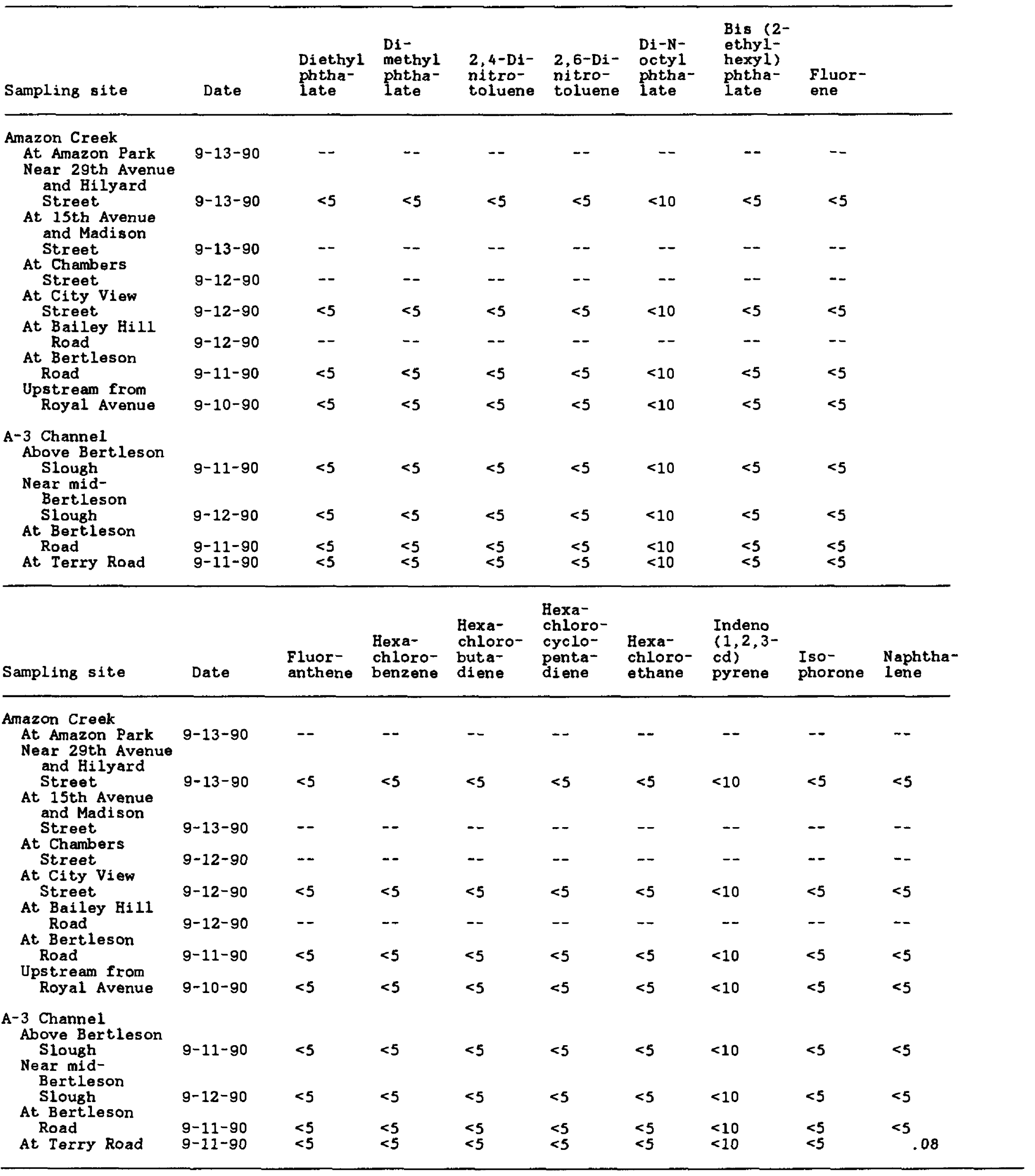


Table 8.--Concentrations of semivolatile priority pollutants in whole water, Amazon Creek Basin, September 1990--Continued

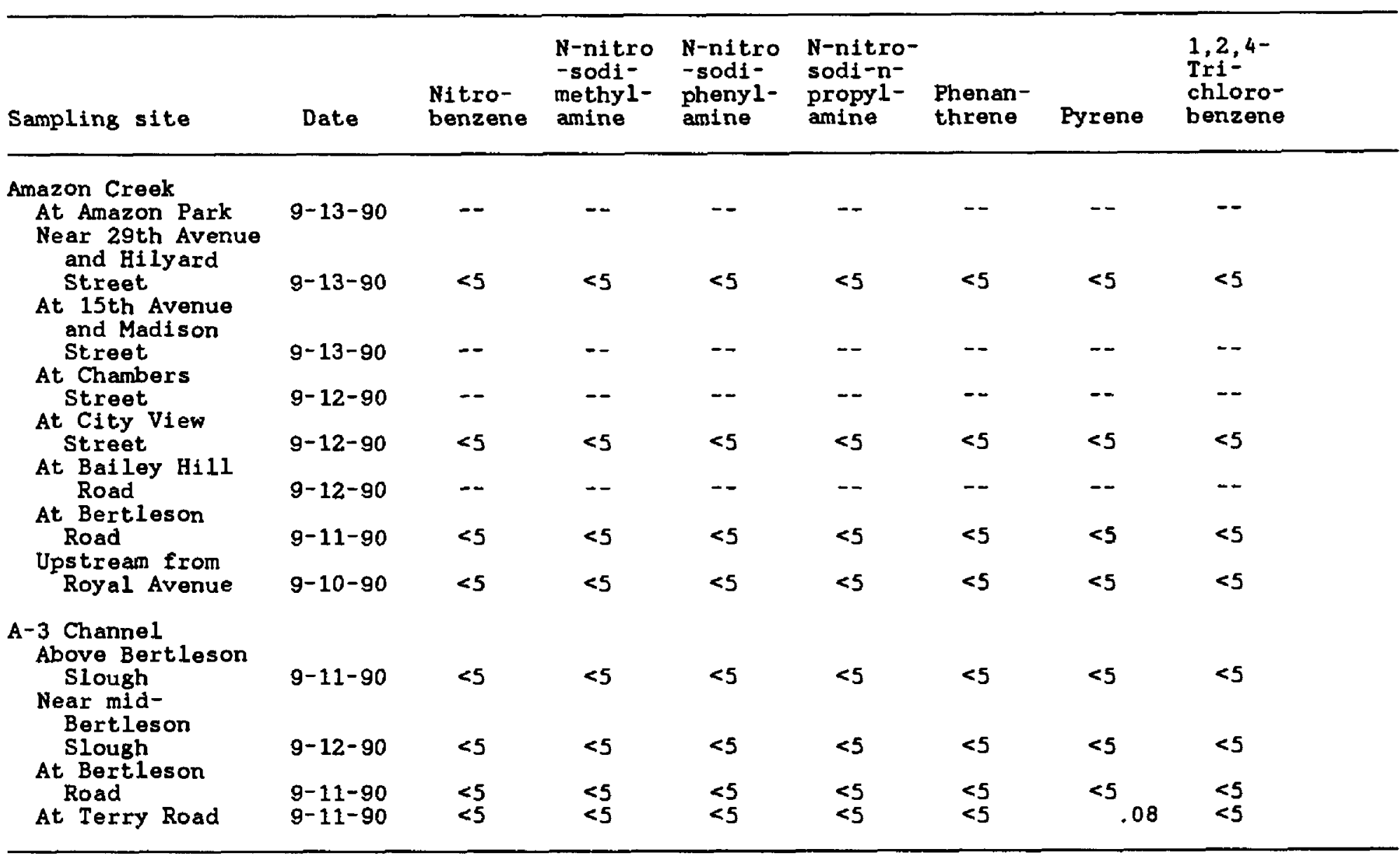

Table 9.--Concentrations of carbamate insecticides in whole water Amazon Creek Bas in. September 19g0 [Insecticide concentrations in micrograms per liter; "--" not analyzed; < = less than]

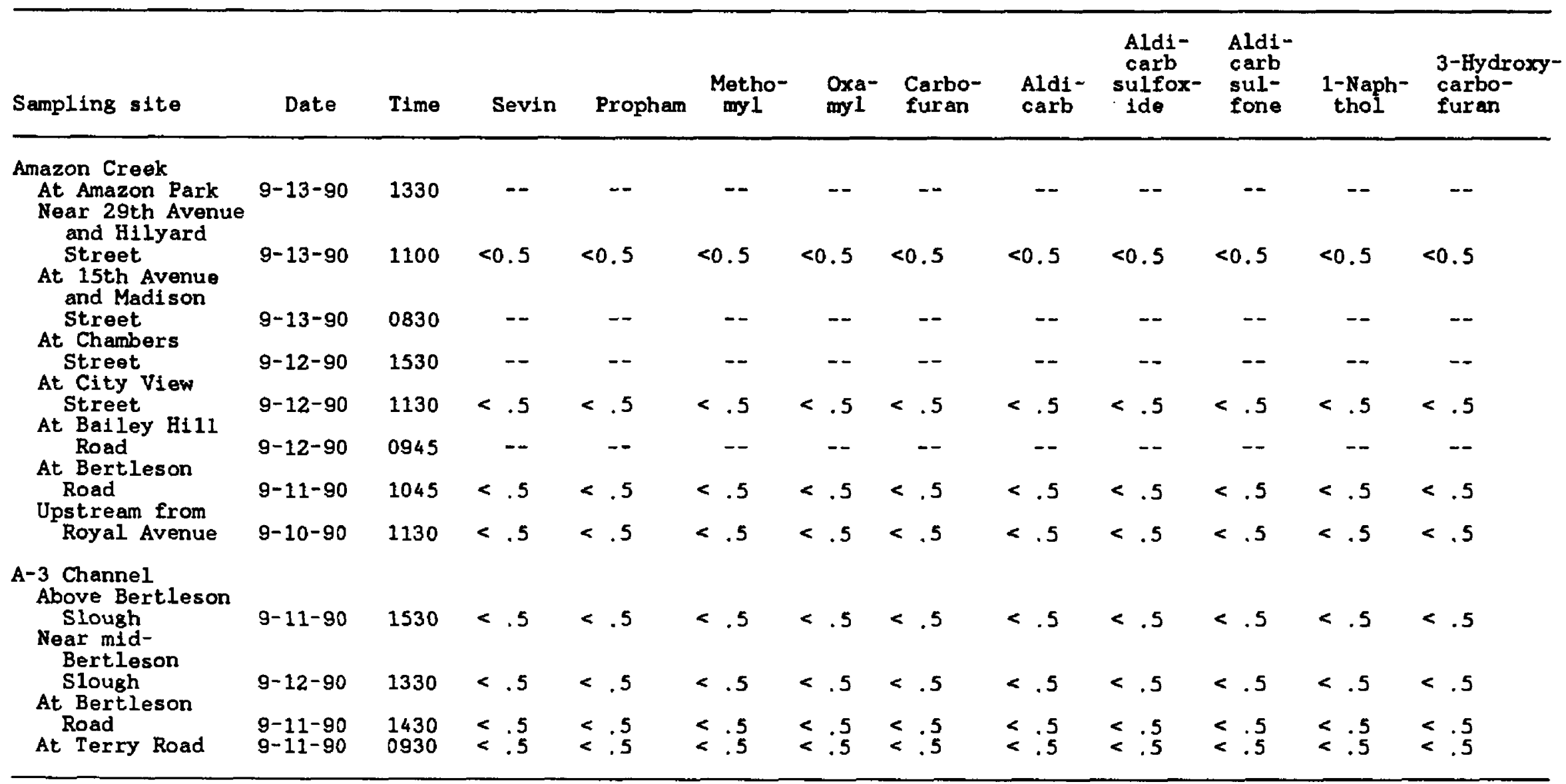


Table 10.--Concentrations of triazine and other nitrogen-containing herbicides in whole water. Amazon Creek Basin, September 1990

[Herbicide concentrations in micrograms per liter; "--" = not analyzed; < = less than]

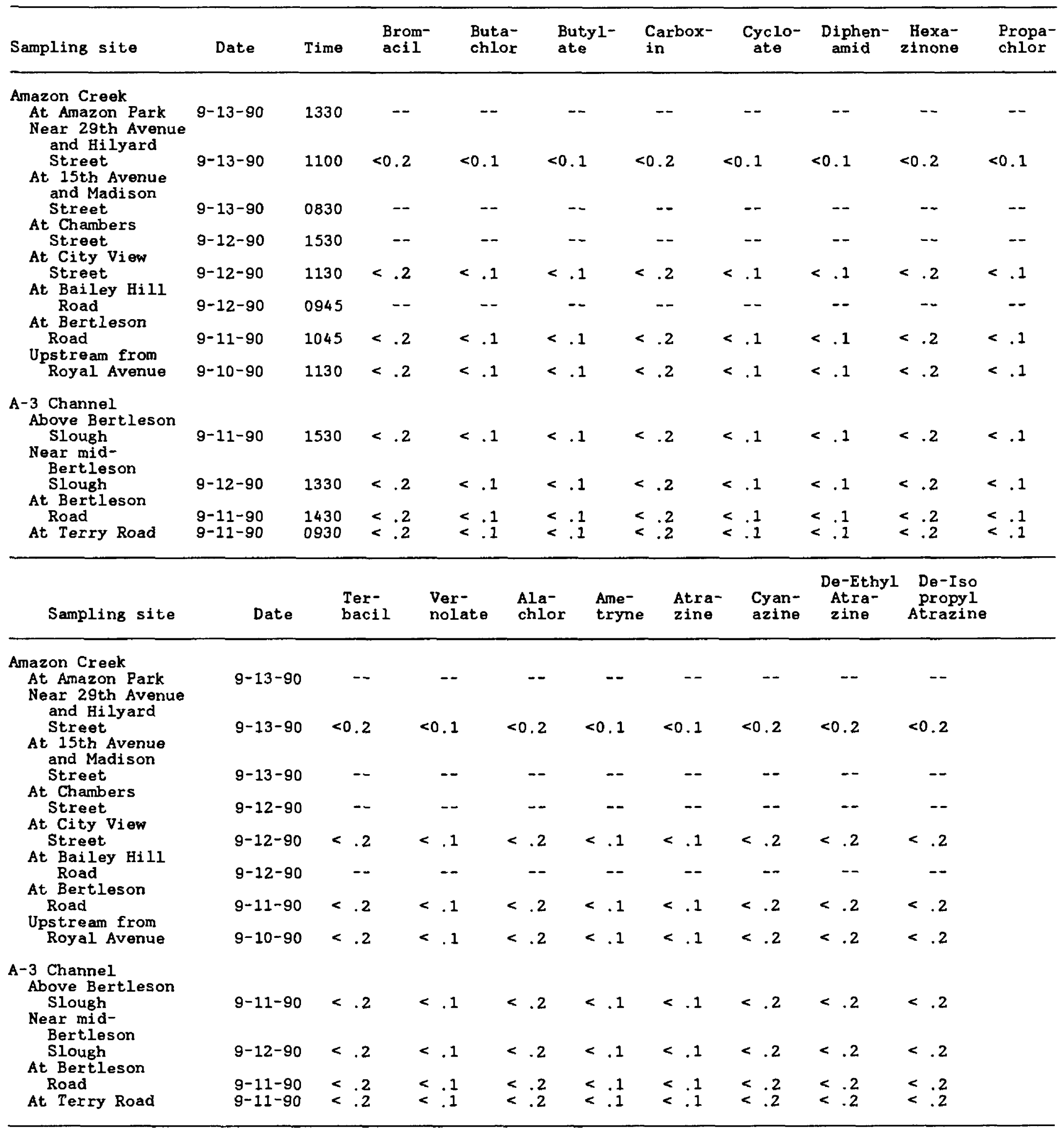


Table 10:-Concentrations of triazine and other nitrogen-containing herbicides in whole water, Amazon Creek Basin, September 1990--Continued

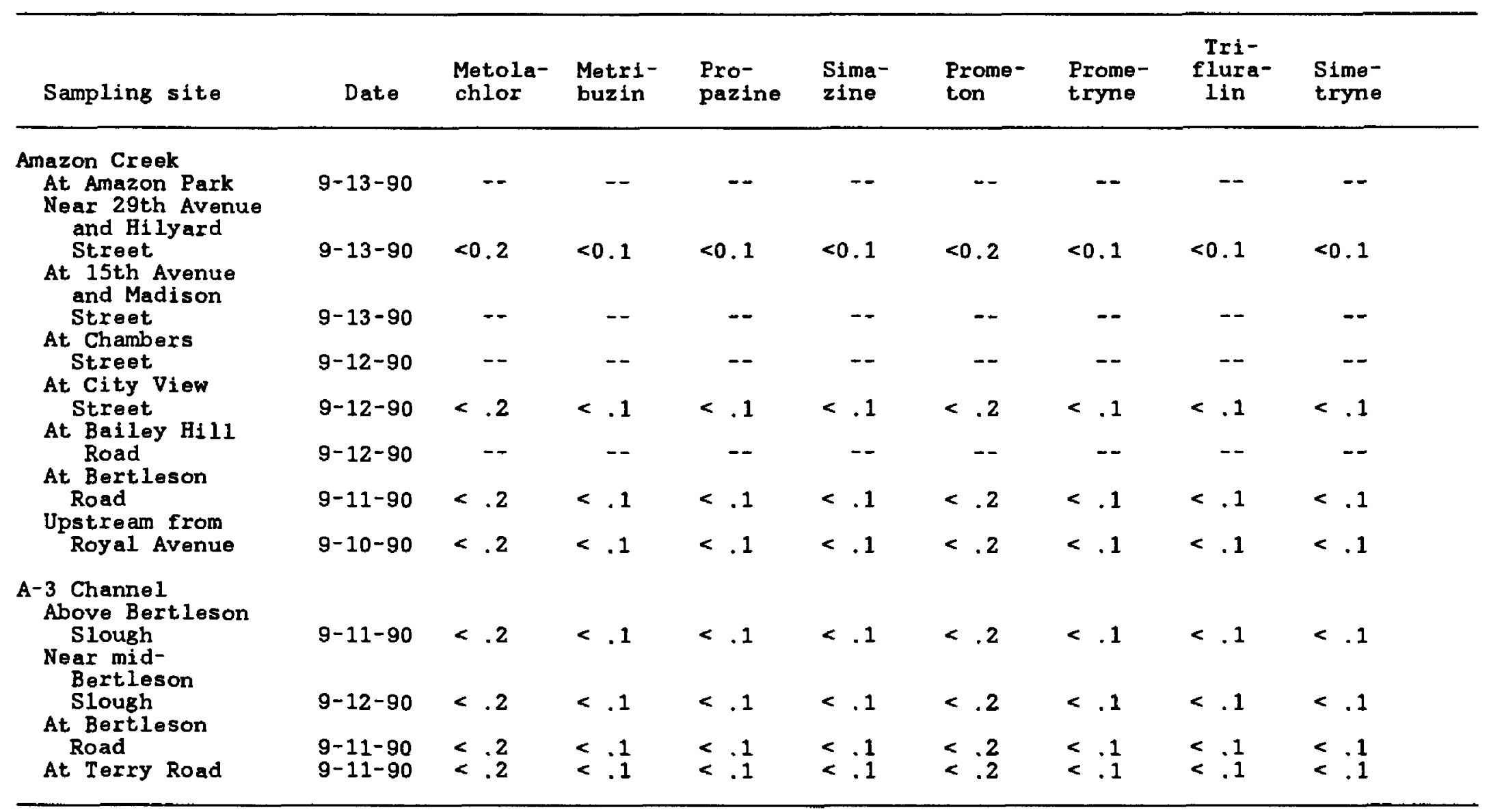


Table 11.--Concentrations of purgeable organic compounds

in whole water, Amazon Creek Bas in, September 1990

[Compound concentrations in micrograms per liter;

$"--"=$ not analyzed; $<=$ less than]

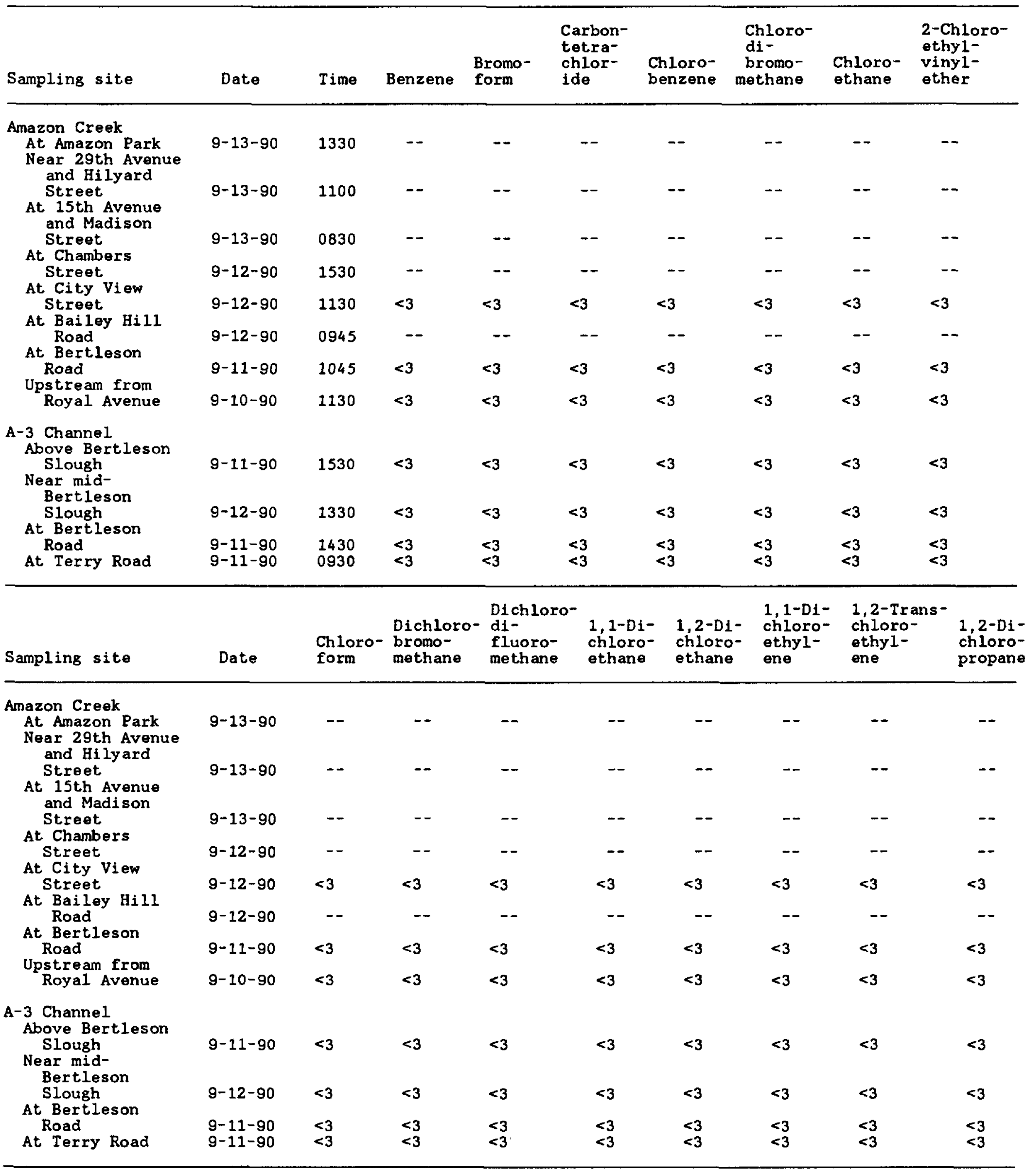


Table 11.--Concentrations of purgeable organic compounds in whole water Amazon Creek Basin, September 1990--Continued

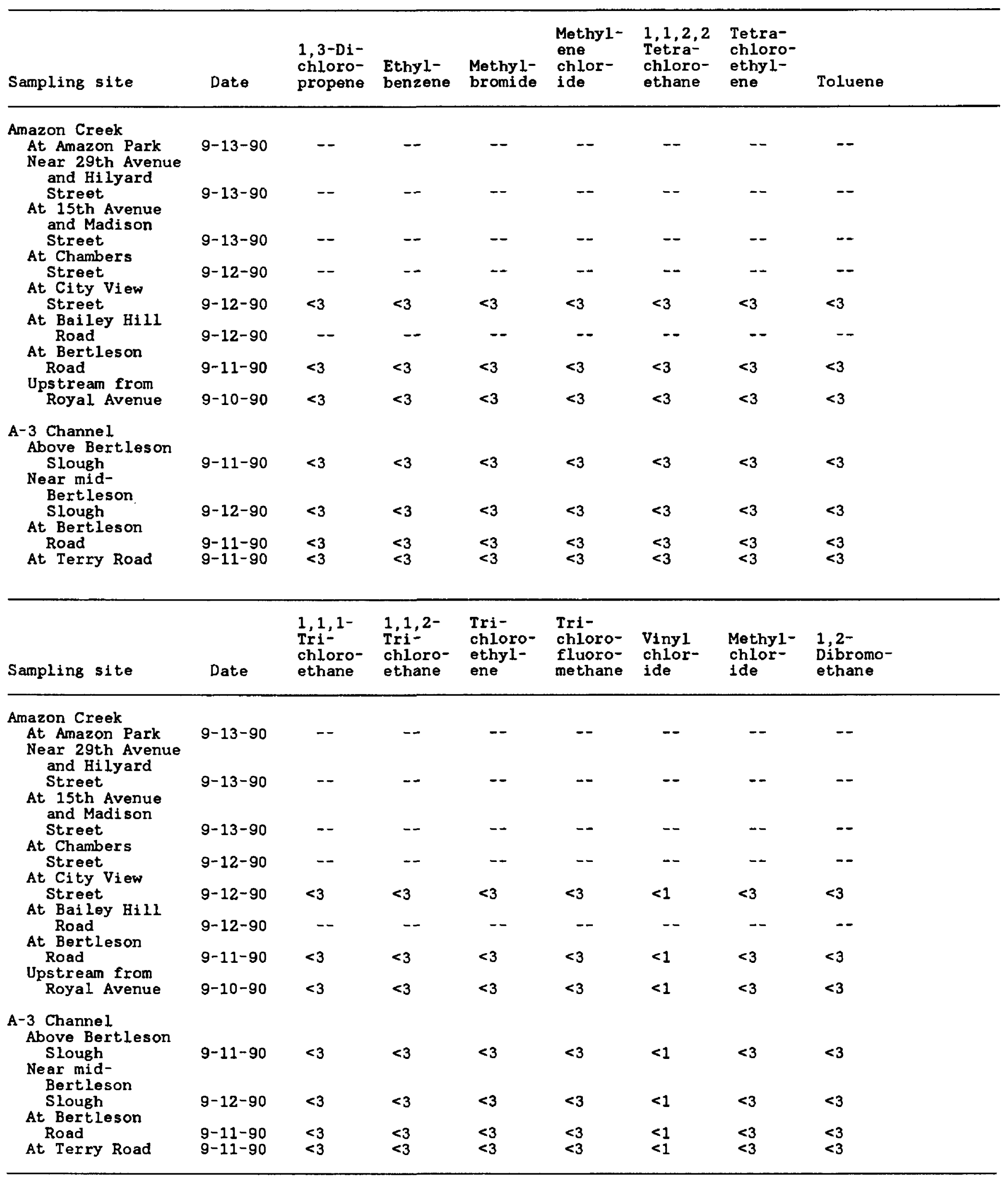


Table 11,--Concentrations of purgeable organic compounds in

whole water Amazon Creek Basin September 1990--Continued

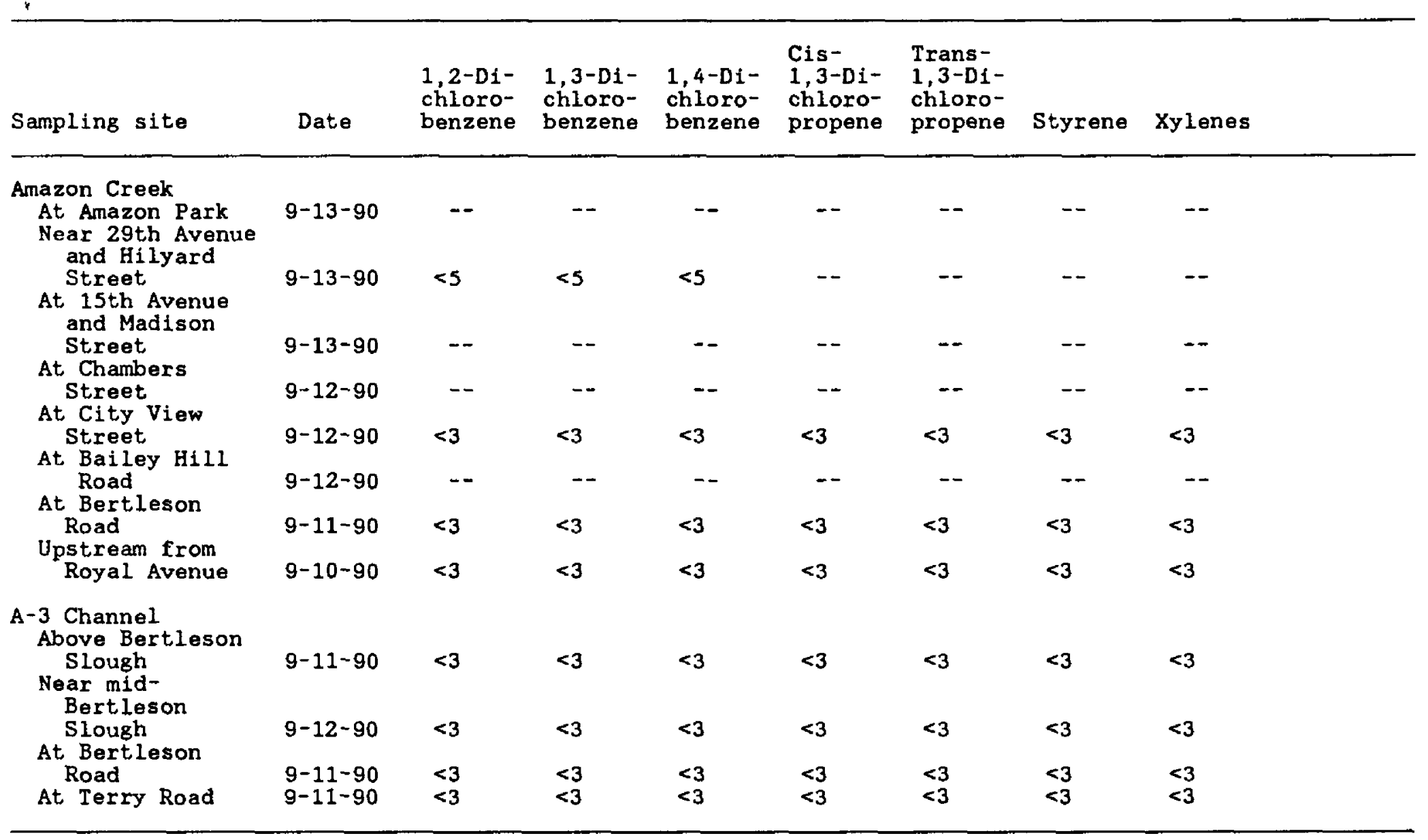


Table 12.--Concentrations of organochlorine compounds in less than 63 micrometer-size bottom sediment, Amazon Creek Basin, September 1990

IDDD = dichlorodiphenyldichloroethane; $D D E=$ dichlorodiphenyldichloroethylene; DDT = dichlorodiphenyltrichloroethane; $\mathrm{PCB}=$ polychlorinated biphenyls ; PCN = polychlorinated naphthalenes. Organochlorine compound concentrations in micrograms per kilogram; $<=$ less than]

\begin{tabular}{|c|c|c|c|c|c|c|c|c|c|c|}
\hline Sampling site & Date & Time & $\begin{array}{l}\text { Per- } \\
\text { thane }\end{array}$ & $\begin{array}{l}\text { Endo- } \\
\text { sulfan }\end{array}$ & Aldrin & $\begin{array}{l}\text { Chlor- } \\
\text { dane }\end{array}$ & DDD & $\mathrm{DDE}$ & DDT & $\begin{array}{l}\text { Di- } \\
\text { eldrin }\end{array}$ \\
\hline \multirow{8}{*}{$\begin{array}{l}\text { Amazon Creek } \\
\text { At Amazon Park } \\
\text { Near 29th Avenue } \\
\text { and Hilyard } \\
\text { Street } \\
\text { At 15th Avenue } \\
\text { and Madison } \\
\text { Street } \\
\text { At Chambers } \\
\text { Street } \\
\text { At City View } \\
\text { Street } \\
\text { At Bailey Hill } \\
\text { Road } \\
\text { At Bertleson } \\
\text { Road } \\
\text { Upstream from } \\
\text { Royal Avenue }\end{array}$} & $9-13-90$ & 1330 & $<1$ & $<0.1$ & $<0.1$ & 70 & 6.6 & 4.4 & $<0.1$ & 8.8 \\
\hline & $9-13-90$ & 1100 & $<1$ & $<.1$ & $<.1$ & 58 & 6.4 & 4.3 & $<.1$ & 8.0 \\
\hline & $9-13-90$ & 0830 & $<1$ & $<.1$ & $<.1$ & 140 & 15 & 9.0 & 3.0 & 7.1 \\
\hline & $9-12-90$ & 1530 & $<1$ & $<.1$ & $<1$ & 120 & 14 & 7.8 & 2.0 & 7.0 \\
\hline & $9-12-90$ & 1130 & $<1$ & $<.1$ & $<.1$ & 80 & 9.2 & 4.8 & $<.1$ & 3.7 \\
\hline & $9-12-90$ & 0945 & $<1$ & $<1$ & $<.1$ & 60 & 4.1 & $<10$ & $<10$ & 2.7 \\
\hline & $9-11-90$ & 1045 & $<1$ & $<.1$ & $<.1$ & 90 & 9.7 & $<10$ & $<10$ & 10 \\
\hline & $9-10-90$ & 1130 & $<1$ & $<.1$ & $<.1$ & 38 & 3.5 & 2.0 & $<.1$ & 2.2 \\
\hline \multirow{3}{*}{$\begin{array}{l}\text { A-3 Channel } \\
\text { Above Bertleson } \\
\text { Slough } \\
\text { Near mid- } \\
\text { Bertleson } \\
\text { Slough } \\
\text { At Bertleson } \\
\text { Road } \\
\text { At Terry Road }\end{array}$} & $9-11-90$ & 1530 & $<10$ & $<1$ & $<.1$ & 40 & 25 & $<20$ & $<10$ & 1.2 \\
\hline & $9-12-90$ & 1330 & $<1$ & $<.1$ & $<1$ & 24 & 120 & 11 & $<.1$ & 1.6 \\
\hline & $\begin{array}{l}9-11-90 \\
9-11-90\end{array}$ & $\begin{array}{l}1430 \\
0930\end{array}$ & $\begin{array}{l}<10 \\
<1\end{array}$ & $\begin{array}{l}<1 \\
<.1\end{array}$ & 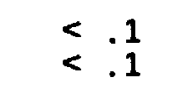 & $\begin{array}{l}60 \\
9.0\end{array}$ & $\begin{array}{l}75 \\
4.6\end{array}$ & $\begin{array}{r}<20 \\
<1\end{array}$ & $\begin{array}{r}<20 \\
<1\end{array}$ & $<1^{.8}$ \\
\hline Sampling site & Date & Endrin & $\begin{array}{l}\text { Hepta- } \\
\text { chlor }\end{array}$ & $\begin{array}{l}\text { Hepta- } \\
\text { chlor } \\
\text { epoxide }\end{array}$ & Lindane & $\begin{array}{l}\text { Toxa- } \\
\text { phene }\end{array}$ & $\mathrm{PCB}$ & PCN & $\begin{array}{l}\text { Meth- } \\
\text { oxy- } \\
\text { chlor }\end{array}$ & Mirex \\
\hline \multirow{8}{*}{$\begin{array}{l}\text { Amazon Creek } \\
\text { At Amazon Park } \\
\text { Near 29th Avenue } \\
\text { and Hilyard } \\
\text { Street } \\
\text { At 15th Avenue } \\
\text { and Madison } \\
\text { Street } \\
\text { At Chambers } \\
\text { Street. } \\
\text { At City view } \\
\text { Street } \\
\text { At Bailey Hill } \\
\text { Road } \\
\text { At Bertleson } \\
\text { Road } \\
\text { Upstream from } \\
\text { Royal Avenue }\end{array}$} & $9-13-90$ & $<0.1$ & $<0.1$ & 1.8 & $<0.1$ & $<10$ & 36 & $<1$ & $<1$ & $<0.1$ \\
\hline & $9-13-90$ & $<.1$ & $<.1$ & 1.8 & $<.1$ & $<10$ & 38 & $<1$ & $<1$ & $<.1$ \\
\hline & $9-13-90$ & .1 & $<1$ & 1.4 & $<.1$ & $<10$ & 630 & $<1$ & $<1$ & $<1$ \\
\hline & $9-12-90$ & $<.1$ & $<1$ & 1.6 & $<.1$ & $<10$ & 150 & $<1$ & $<1$ & $<1$ \\
\hline & $9-12-90$ & $<.1$ & $<.1$ & .8 & $<.1$ & $<10$ & 56 & $<1$ & $<1$ & $<.1$ \\
\hline & $9-12-90$ & $<.1$ & $<.1$ & $<.1$ & $<.1$ & $<10$ & 24 & $<1$ & $<1$ & $<.1$ \\
\hline & $9-11-90$ & $<.1$ & $<.1$ & $<.1$ & $<.1$ & $<10$ & 48 & $<1$ & $<1$ & $<.1$ \\
\hline & $9-10-90$ & $<.1$ & $<.1$ & $<.1$ & $<.1$ & $<10$ & 20 & $<1$ & $<1$ & $<.1$ \\
\hline \multirow{3}{*}{$\begin{array}{l}\text { A-3 Channel } \\
\text { Above Bertleson } \\
\text { Slough } \\
\text { Near mid- } \\
\text { Bertles on } \\
\text { Slough } \\
\text { At Bertleson } \\
\text { Road } \\
\text { At Terry Road }\end{array}$} & $9-11-90$ & $<.1$ & $<.1$ & $<.1$ & $<1$ & $<10$ & 450 & $<1$ & $<1$ & $<.1$ \\
\hline & $9-12-90$ & $<.1$ & $<1$ & $<.1$ & $<.1$ & $<10$ & 54 & $<1$ & $<1$ & $<.1$ \\
\hline & $\begin{array}{l}9-11-90 \\
9-11-90\end{array}$ & $\begin{array}{l}<.1 \\
<.1\end{array}$ & $\begin{array}{l}<.1 \\
<.1\end{array}$ & $\begin{array}{l}<.1 \\
<.1\end{array}$ & $<1$ & $\begin{array}{l}<10 \\
<10\end{array}$ & $\begin{array}{r}430 \\
58\end{array}$ & $\begin{array}{l}<1 \\
<1\end{array}$ & $<1$ & $<<1$ \\
\hline
\end{tabular}


Table 13.--Concentrations of semivolatile priority pollutants in less than 63 micrometer-size bottom sediment, Amazon Creek Basin, September 1990

[Pollutant concentrations in microgram per kilogram; < = less than]

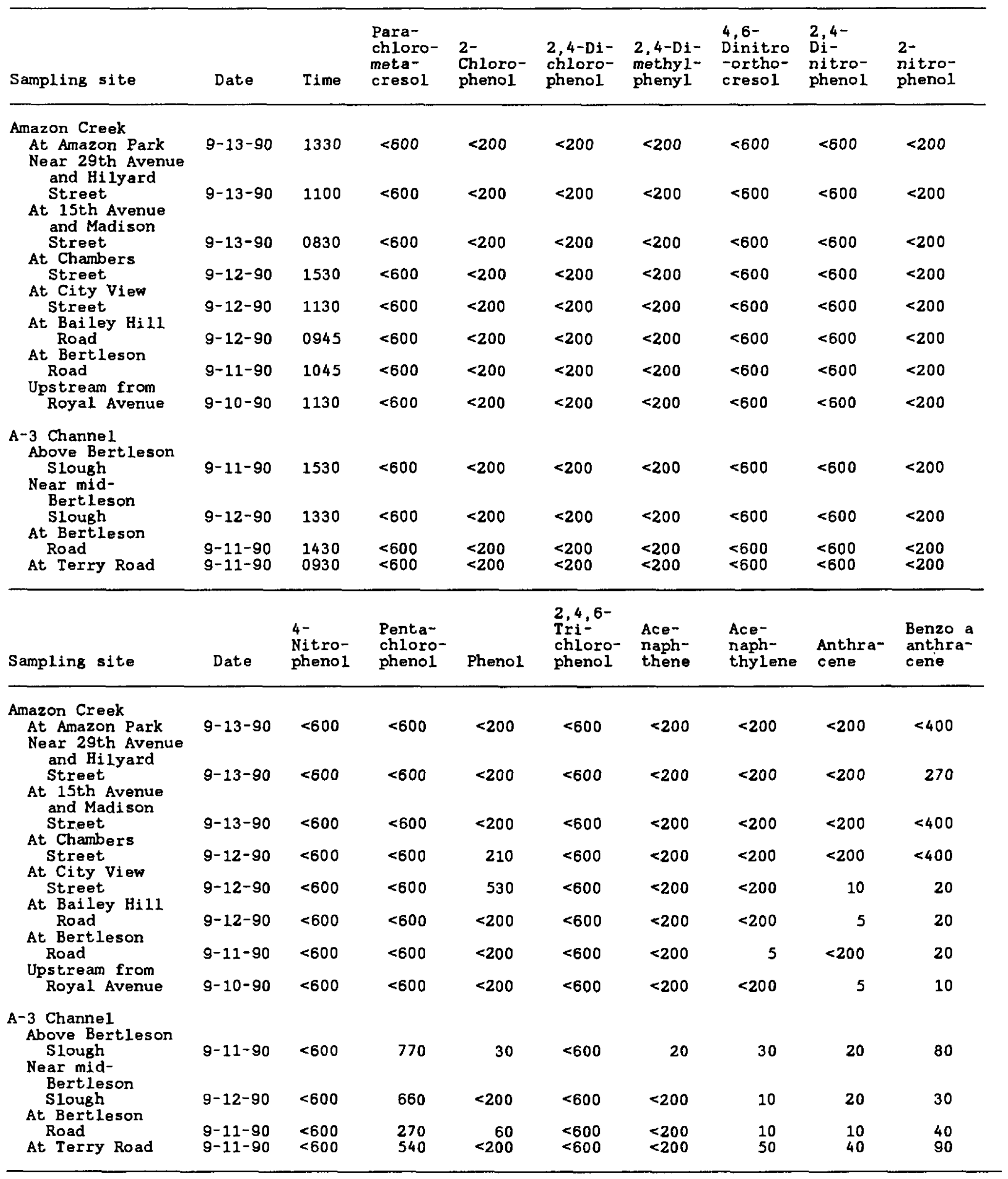


Table 13. - Concentrations of semivolatile priority pollutants in less than 63 micrometer-size bottom sediment, Amazon Creek Basin, September 1990--Continued

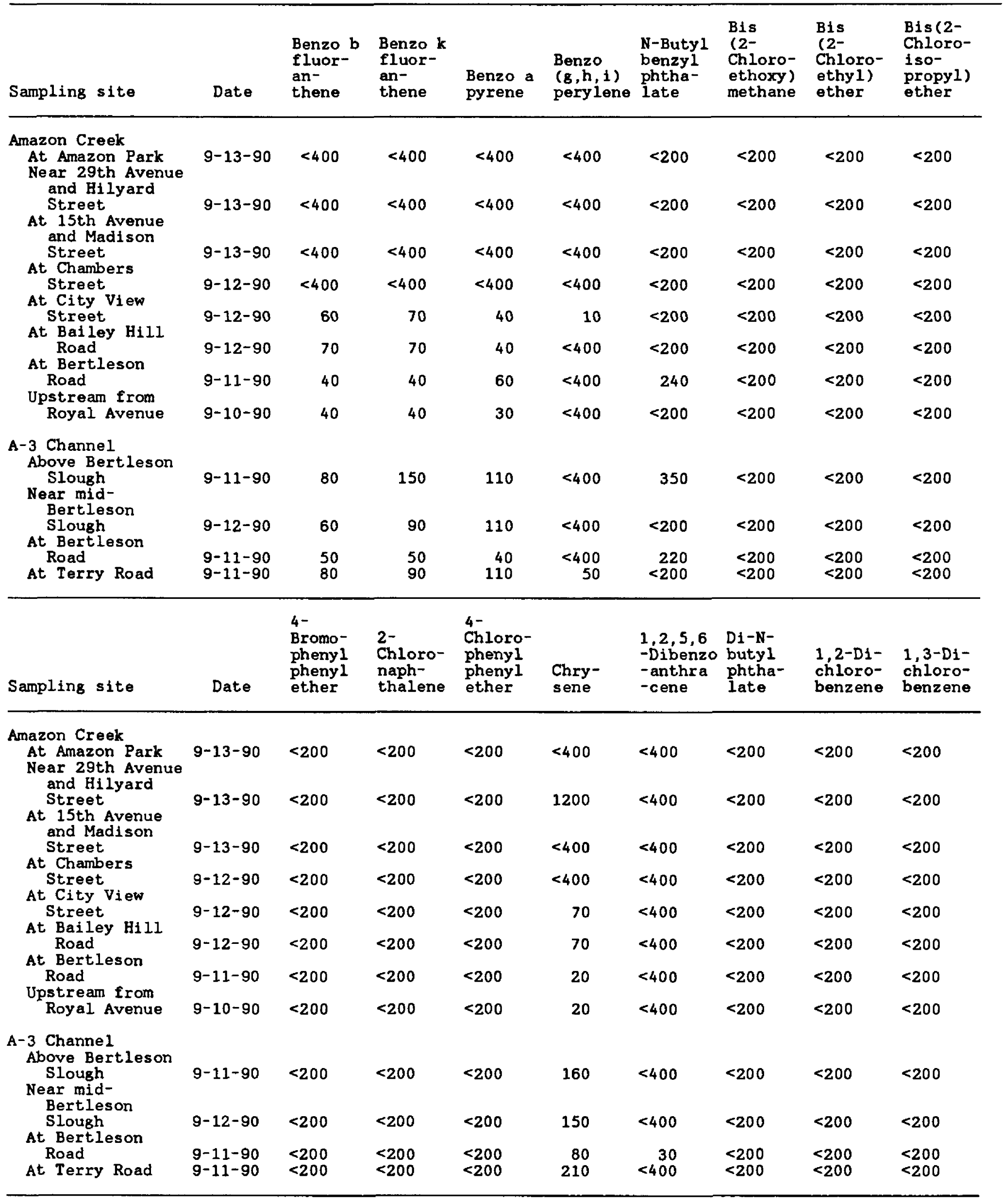


Table 13. - Concentrations of semivolatile priority pollutants in less than 63 micrometer-size bottom sediment, Amazon Creek Basin, September 1990--Continued

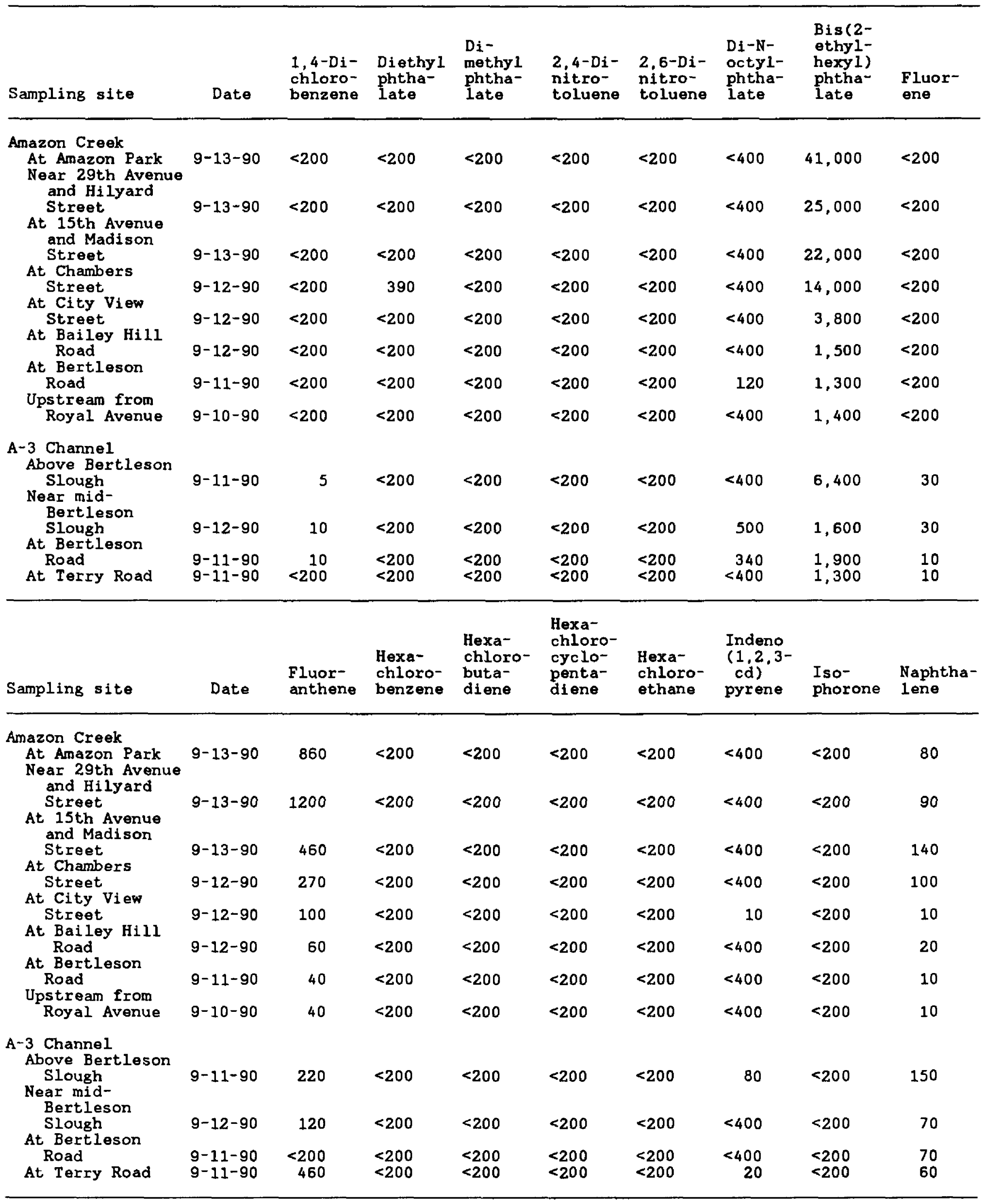


Table 13.--Concentrations of semivolatile priority pollutants in less than 63 micrometer-size bottom sediment, Amazon Creek Basin, September 1990--Continued

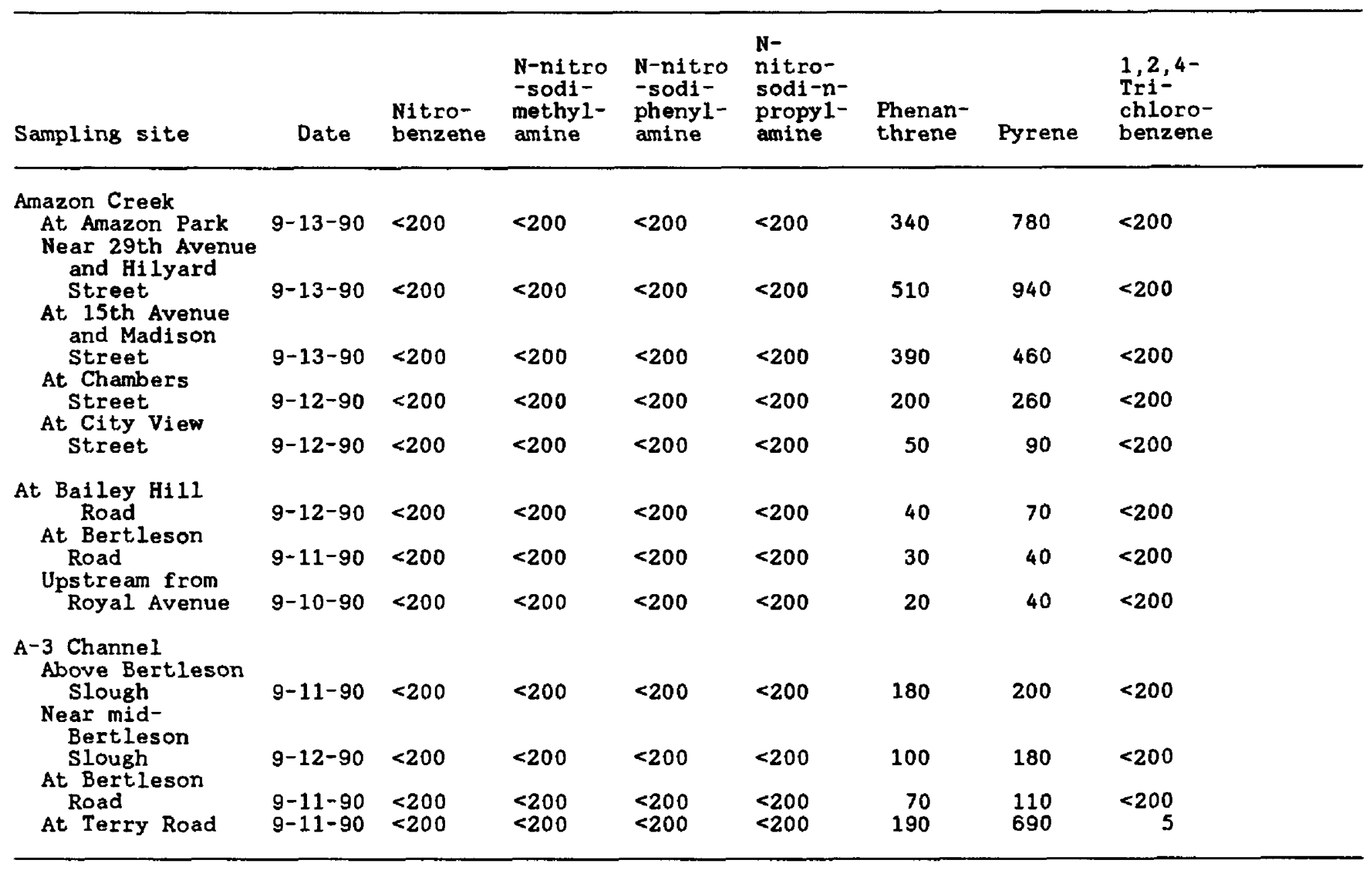


Table 14. - Concentrations of total trace elements in bottom sediment. Amazon Creek Bas in. September 1990

[Ag = silver; $\mathrm{Cu}=$ copper; $\mathrm{Pb}=$ lead; $\mathrm{Zn}=21 \mathrm{nc} ; \mathrm{Ni}=\mathrm{nickel;} \mathrm{Co}=$ cobalt; $\mathrm{Cd}=\mathrm{cadmium} ; \mathrm{Cr}=\mathrm{chromi}$ (um; $\mathrm{Hg}=$ mercury; $\mathrm{As}=$ arsenic: $\mathrm{Sb}=$ antimony: $\mathrm{Mn}=$ manganese: $\mathrm{T}_{1}=\mathrm{titanium}$ : Se = selenium; Fe = iron;

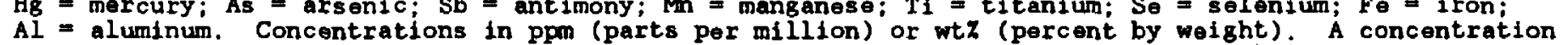

of $1.0 \mathrm{wtz}=10,000 \mathrm{ppm}$. TOC = total organic carbon, $\mu \mathrm{m}=$ micrometers, < $=$ less than, $>=8 \mathrm{reater}$ than

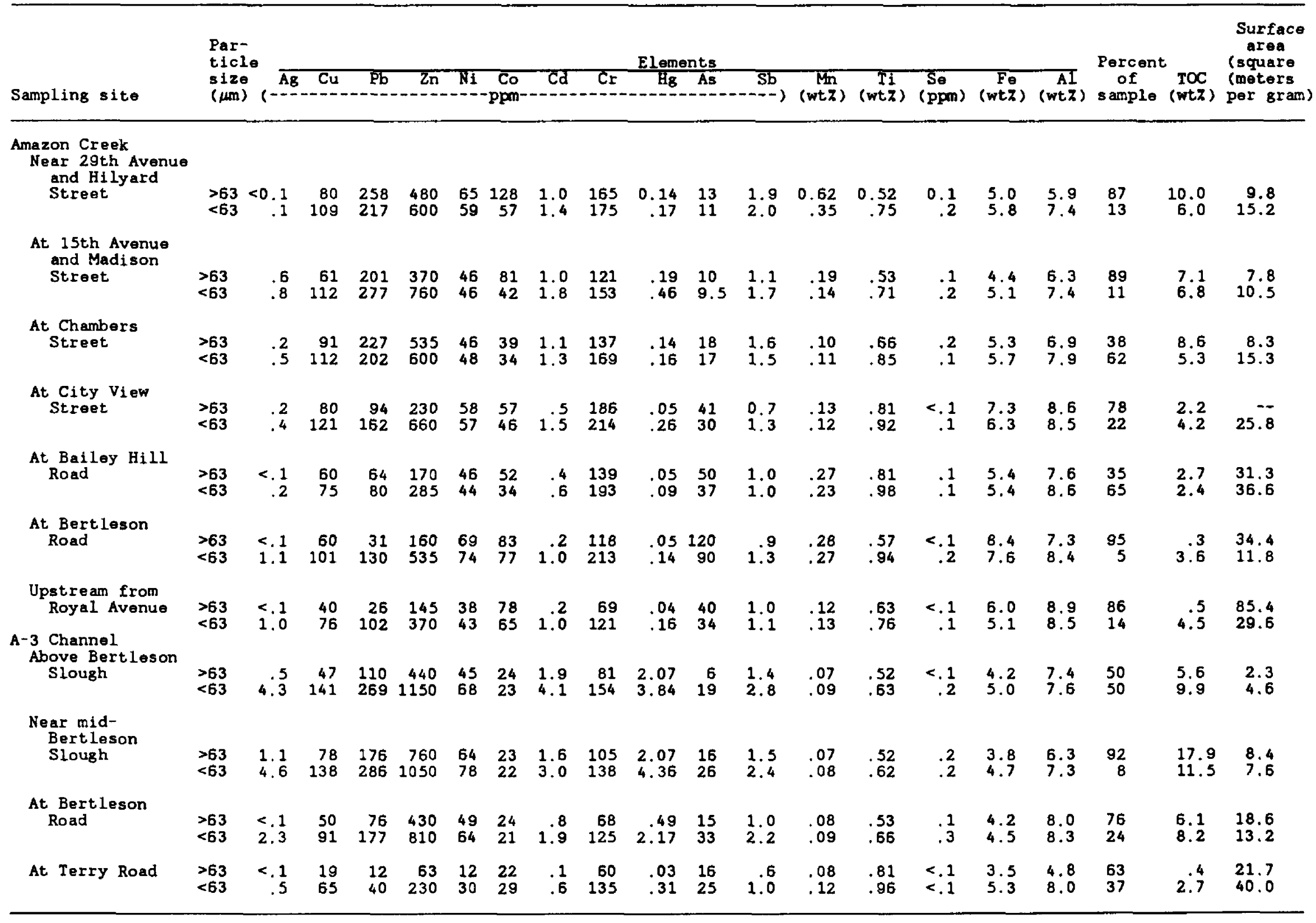

